\title{
Quantification of mass transfers and mineralogical transformations in a thrust fault (Monte Perdido thrust unit, southern Pyrenees, Spain)
}

\author{
Vincent Trincal $^{\mathrm{a}, *}$, Delphine Charpentier ${ }^{\mathrm{a}}$, Martine D. Buatier ${ }^{\mathrm{a}}$, Bernard Grobety ${ }^{\mathrm{b}}$, \\ Brice Lacroix ${ }^{c}$, Pierre Labaume ${ }^{\mathrm{d}}$, Jean-Pierre Sizun ${ }^{\mathrm{a}}$ \\ ${ }^{a}$ Chrono-Environnement, UMR 6249, Université de Franche-Comté, 16 rte de Gray, 25000 Besançon, France \\ ${ }^{\mathrm{b}}$ Department of Geosciences, University of Fribourg, $\mathrm{CH}-1700$ Fribourg, Switzerland \\ ${ }^{\mathrm{c}}$ Institut de Minéralogie et Géochimie, UNIL-Dorigny Bâtiment Anthropole, CH-1015 Lausanne, Switzerland \\ d Géosciences Montpellier, UMR 5243, Université Montpellier 2, 34095 Montpellier, France
}

In fold-and-thrust belts, shortening is mainly accommodated by thrust faults which are preferential zones for recrystallisation and mass transfer. This study focuses on a detachment fault related to the emplacement of the Monte Perdido thrust unit in the southern Pyrenees. The studied fault zone consists of a $10 \mathrm{~m}$ thick intensively foliated phyllonite developed within the Millaris marls, of Eocene age. The lithological homogeneity of the hanging wall and footwall allows us to compare the Millaris marls outside the fault zone with the highly deformed marls located in the fault zone and to quantify the chemical, mineralogical and volumetric changes related to deformation processes along the fault.

The Millaris marls are composed of detrital quartz, illite, chlorite, minor albite and pyrite, in a micritic calcite matrix. In the fault zone, the cleavage planes are marked by clay minerals and calcite \pm chlorite veins attest to fluid-mineral interactions during deformation.

The mineral proportions in all samples from both the fault zone and Millaris marls have been quantified by two methods: (1) X-ray diffraction and Rietveld refinement, and (2) bulk chemical analyses as well as microprobe analyses to calculate modal composition. The excellent agreement between the results of these two methods allows us to estimate mineralogical variations using a modification of the Gresens' equation. During fault activation, up to $45 \mathrm{wt} \%$ of calcite was lost while the amounts of quartz and chlorite remained unchanged. Illite content remained constant to slightly enriched. The mineralogical variations were coupled with a significant volume loss (up to 45\%) mostly due to the dissolution of micritic calcite grains. Deformation was accompanied by pressure solution and phyllosilicates recrystallisation. These processes accommodated slip along the fault. They required fluids as catalyst, but they did not necessitate major chemical transfers.

\section{Introduction}

In fold-and-thrust belts, major thrust faults have a strong impact on fluid flow and vice versa (e.g. McCaig et al., 2000). Fluid-rock interactions and fault activation might be responsible for chemical and mineralogical modifications in the fault zone. These modifications might have major impact on fault sealing potential but also on fault weakening (e.g. Byerlee, 1978; Carpenter et al., 2011; Gratier et al.

\footnotetext{
* Corresponding author. Tel.: +33381666 051.

E-mail addresses: vincent trincal@univ-fcomtefr (V. Trincal), delphine. charpentier@univ-fcomte.fr (D. Charpentier), martine.buatier@univ-fcomte.fr (M D. Buatier), bernard.grobety@unifr.ch (B. Grobety), brice.lacroix@unil.ch (B. Lacroix), labaume@gm.univ-montp2.fr (P. Labaume), jean-pierre.sizun@univfcomte.fr (J.-P. Sizun).
}

2013; Numelin et al., 2007). Quantifying mass transfers associated with deformation and fluid-rock interactions in faults affecting sedimentary rock is a difficult challenge because sedimentary rocks have generally heterogeneous composition and mineralogical quantification is hard because of the small size of the minerals.

In the Monte Perdido thrust fault, the mechanisms and the conditions of deformation have been well constrained in previous studies by Lacroix et al. (2011, 2012). These authors combined structural, geochemical and fluid inclusion analyses to determine the PT conditions of deformation and origin of the fluids in fault zones related to the emplacement of the Monte Perdido thrust unit (SW-Central Pyrenees). They showed that deformation in fault zones led to the development of a pervasive pressure solution cleavage as well as the formation of calcite-quartz shear and extension veins. The oxygen isotope analyses of syntectonic calcite 
and quartz veins combined with fluid inclusion microthermometry allowed the determination of the P-T conditions of deformation, i.e. $\sim 208^{\circ} \mathrm{C} / 570$ bar for the main shearing stage and $\sim 240{ }^{\circ} \mathrm{C} / 650$ bar for the late shearing stage of the fault zones. Moreover, Lacroix et al. (2012) demonstrated through stable isotope analyses on carbonate veins that pressure solution with local mass transfer of calcite seems to be the major mechanism of this aseismic deformation. The pressure solution deformation mechanism might cause concentration of insoluble clay minerals and mechanical weakening within the fault zone (Lacroix et al., 2013). In the same fault zones, Buatier et al. (2012) demonstrated that clay minerals did not only act as passive insoluble mineralogical phases but that phyllosilicates dissolution and precipitation occurred during deformation in the most deformed sediments.

The aim of the present study is (1) to quantify the mass transfers during deformation and mineralogical reactions in a fault zone related to the emplacement of the Monte Perdido thrust unit and (2) to characterise the mineralogical reactions due to fluid-rock interactions in this fault zone. Mineralogical reactions have been deduced from electron microscopy and X-ray diffraction analyses, and quantified by Rietveld refinement. Mass transfers have been studied by bulk rock chemical analyses coupled with chemical point analyses and then quantified using mass balance calculation. Previous studies (e.g. Buatier et al., 2012; Lacroix et al., 2012, 2013) were realised on three selected outcrops, two outcrops corresponding to the Monte Perdido sole thrust with footwall and hanging wall of different lithologies (the Torla thrust) and the third one is a detachment fault inside the thrust unit (the Millaris fault). The latter fault was chosen for the present study because the similar marl lithology of the footwall and hanging wall is compatible with the assumption that the initial states of the sediments on both sides of the fault zone before deformation were identical.

\section{Geological setting and outcrop description}

The Pyrenean belt is a doubly-vergent orogenic wedge formed during the collision of the Iberian and European plates from the Late Cretaceous to the early Miocene (e.g. Muñoz, 1992; Roure et al., 1989; Teixell, 1998). The south-vergent thrust system comprises imbricated basement thrusts, which form the anticlinal stack of the Axial Zone and pass southwards to detachment levels below the cover thrust units of the South-Pyrenean Zone (Fig. 1).

The studied area is located in the South-Pyrenean Zone, in the northern part of the Jaca Basin (Fig. 1). Above the Triassic detachment level, the stratigraphy of the northern Jaca Basin comprises Cenomanian to Santonian platform limestones overlain by the syn-orogenic succession with, from bottom to top, Campanian to early Eocene (lower Ypresian) platform carbonates (divided in (i) Campanian-Maastrichtian sandy limestones and sandstones and (ii) Paleocene to lowermost Ypresian dolomites and limestones), lower Ypresian marls (the Millaris marls), the YpresianLutetian turbidites of the Hecho Group and Bartonian to lower Oligocene coastal and continental deposits (e.g. Teixell, 1996) (Fig. 2). In the east, outer shelf carbonates are intercalated between the Millaris marls and turbidites. At the northern edge of the Jaca basin, the Triassic evaporites are absent and the Upper Cretaceous limestones rest directly on the Paleozoic basement of the Axial Zone.

The two major thrust units in the vicinity of the study area are the Monte Perdido and Gavarnie thrusts units with about $6 \mathrm{~km}$ and $10 \mathrm{~km}$ displacement respectively (Séguret, 1972; Teixell, 1996) (Fig. 2). To the north, the Monte Perdido sole thrust is a detachment located in the lower part of the Upper Cretaceous limestones. Southwards, the sole thrust cuts across the carbonate succession to reach an upper detachment in the early Eocene Millaris marls. Inside the Monte Perdido unit, an upper duplex system is located between a sole detachment in the upper part of the Campanian-Maastrichtian sandstone (Grès du Marboré Formation) and a roof detachment in the Millaris marls. To the north, the Monte Perdido thrust unit is folded by the hanging wall culmination of the underlying Gavarnie basement thrust, which passes southwards to the Triassic detachment level. Both the Monte Perdido and Gavarnie units are affected by a regional pressure-solution cleavage formed during their emplacement (Labaume et al., 1985; Oliva-Urcia et al., 2009; Séguret, 1972; Teixell, 1996). Both units are tilted southwards by the hanging wall culmination of another underlying basement thrust (Mutti et al., 1988). The Monte Perdido thrusting is dated to the mid-late Lutetian to end Bartonian ( 46-38 Ma). The Gavarnie thrusting is dated to the Priabonian to Rupelian by stratigraphy (Teixell, 1996) and to Maastrichtian-Priabonian by $\mathrm{Ar}-\mathrm{Ar}$ isotopic dating on authigenic illite (Rahl et al., 2011).

The studied fault zone (the Millaris fault) is located in the lower Ypresian Millaris marls, which are sub-horizontal along the studied outcrop. The fault zone is a $10 \mathrm{~m}$ thick shear zone sub-parallel to bedding bounded by major shear surfaces (Fig. 3). Outside the fault zone, the Millaris marls are affected by a north-dipping regional cleavage. Inside the fault zone, the fault-rock is intensely deformed and darker than the host marls, featuring a well-developed, closely-

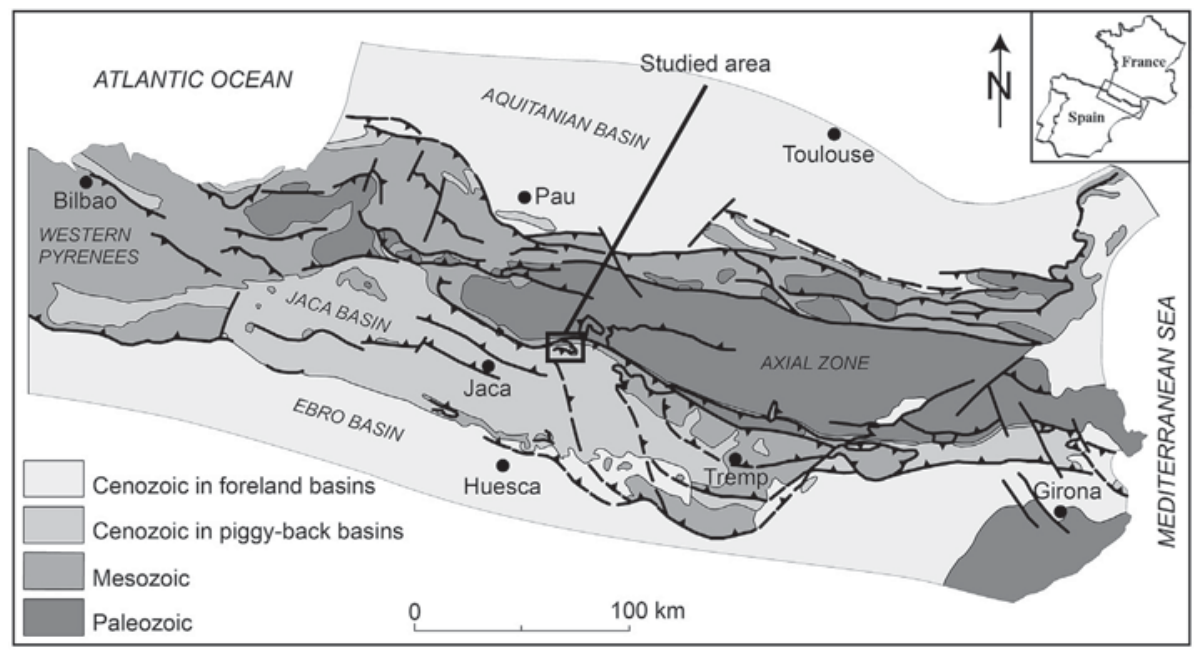

Figure 1. Structural map of the Pyrenees with the location of study area (modified from Teixell, 2000). 

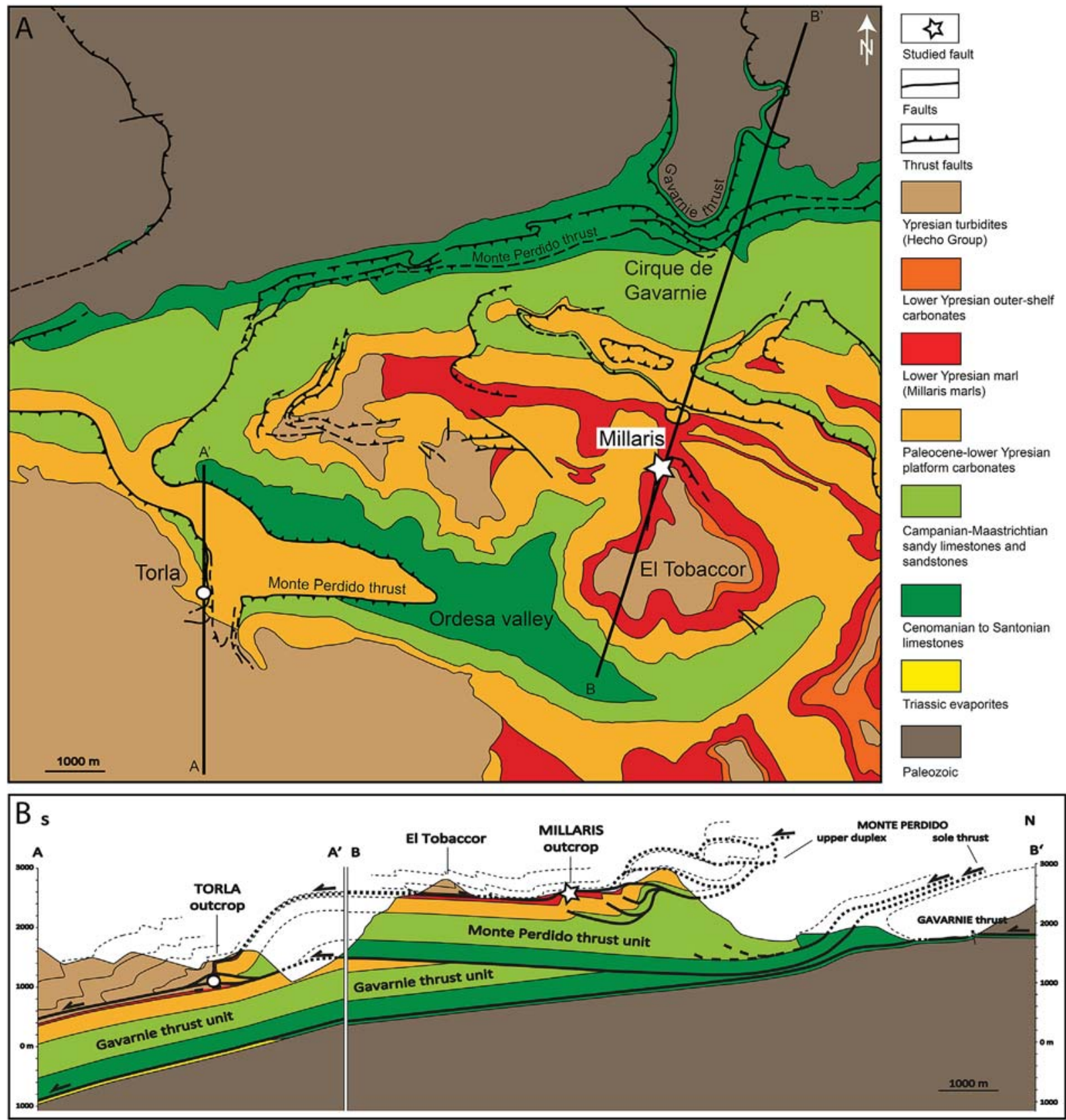

Figure 2. (A) Geological map of the studied area simplified from the Bajaruelo and Broto 1:50,000 scale IGME maps. (B) Structural cross-section of the Monte Perdido massif (location: lines in A). The studied outcrop (Millaris) is located by the white star with $42^{\circ} 40^{\prime} 10^{\prime \prime} \mathrm{N}$ in latitude and $0^{\circ} 0^{\prime} 59^{\prime \prime} \mathrm{W}$ in longitude. Coordinates are $42^{\circ} 37^{\prime} 25.38^{\prime \prime} \mathrm{N}-0^{\circ} 6^{\prime} 31.71^{\prime \prime} \mathrm{O}$ for $\mathrm{A} ; 42^{\circ} 40^{\prime} 7.92^{\prime \prime} \mathrm{N}-0^{\circ} 6^{\prime} 22.57^{\prime \prime} \mathrm{O}$ for $\mathrm{A}^{\prime} ; 42^{\circ} 44^{\prime} 7.21^{\prime \prime} \mathrm{N}-0^{\circ} 1^{\prime} 17.08^{\prime \prime} \mathrm{E}$ for B and $42^{\circ} 36^{\prime} 49.23^{\prime \prime} \mathrm{N}-0^{\circ} 2^{\prime} 33.13^{\prime \prime} \mathrm{O}$ for $\mathrm{B}^{\prime}$.

spaced S-C type microstructures with north-dipping cleavage surfaces attesting top-to-the-south displacement (Fig. 3B). Calcitequartz shear veins are common along the shear surfaces but we have not been able to estimate their volume. Centimetre thick shear veins deformed by late folding and microfaults related to the cleavage development underline the boundaries of the fault zone. The deformation structures and microstructures in the Millaris fault zone have been described in detail by Lacroix et al. (2011).

This fault zone probably corresponds to the roof detachment of the upper duplex inside the Monte Perdido thrust unit (Fig. 2), implying a kilometric extension and several hundred of metres displacement. However, field observation showed that the lateral extension of the fault zone is limited to a few hundred metres, suggesting it may correspond only to a branch of the detachment, having accommodated only a limited displacement.

\section{Methods and sampling}

For the present study, sampling was conducted along a vertical transect through the fault zone (Fig. 3B). Three samples from host rock (hanging wall and footwall) were collected up to $10 \mathrm{~m}$ outside of the fault zone. Nine samples (including one divided into seven sub-samples) were collected in the fault zone and at the interface between the fault zone and the host marls. Sampling was focused on the highly deformed matrix, avoiding the macroscopic calcite veins.

\subsection{Microscopy}

Petrographic characteristics of the 12 samples were studied by optical microscopy on standard polished thin sections. Microstructures and mineral assemblages were analysed at the University of 

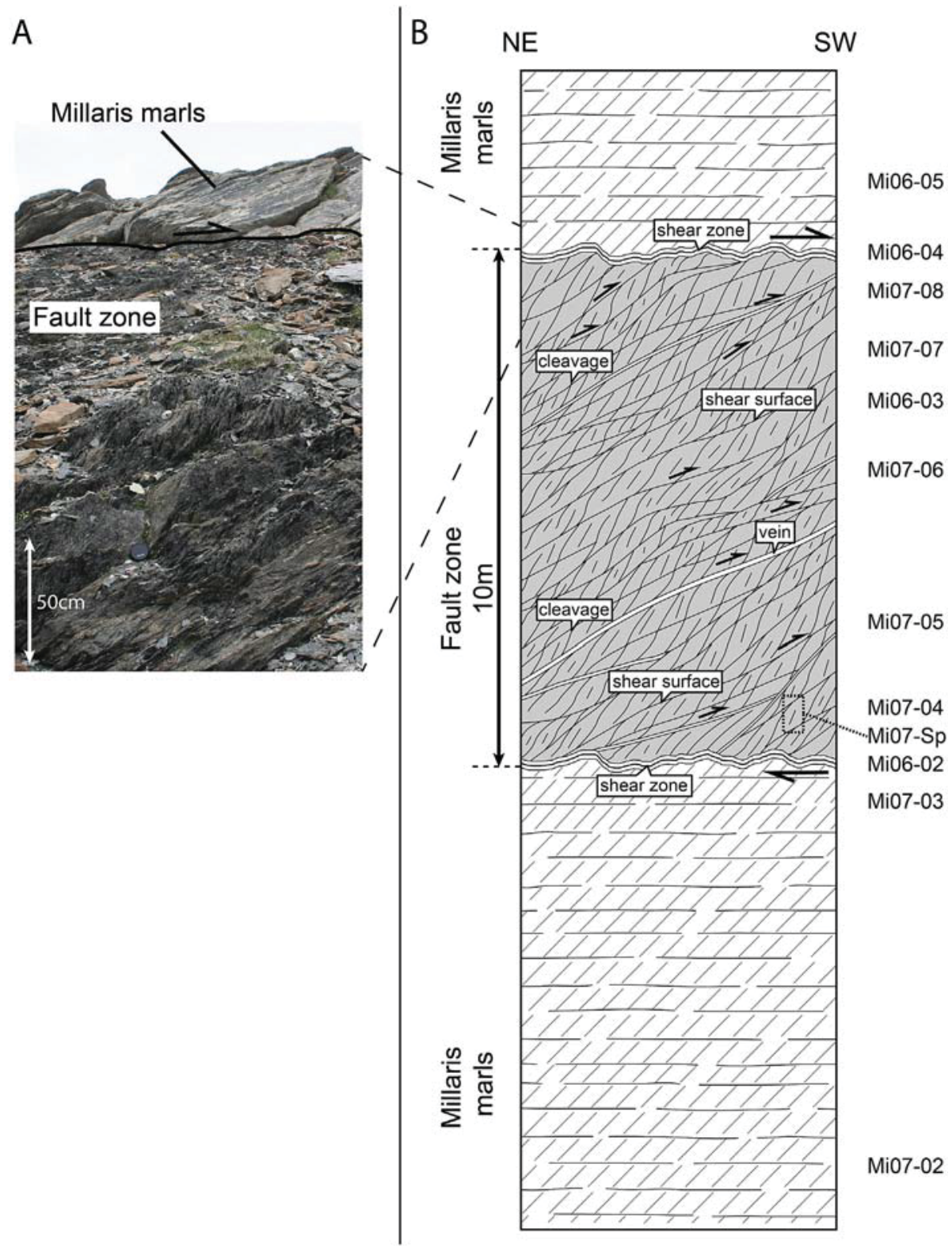

Figure 3. (A) Millaris outcrop photography with lower Ypresian Millaris marls hanging wall and fault zone. Note the difference in colour and cleavage intensity between the fault zone and hanging wall (comments in the text). (B) Schematic diagram of the structural organisation of the studied fault zone outcrop, modified from Lacroix et al. (2011). (For interpretation of the references to colour in this figure legend, the reader is referred to the web version of this article.)

Franche-Comté (Besançon) with a JEOL JSM5600 scanning electron microscope coupled with a FONDIS energy dispersive analyser (EDS). Images were obtained with backscattered electrons at $20 \mathrm{kV}$.

\subsection{Electron microprobe analyses}

The chemical composition of calcite and phyllosilicates from the host rock and the fault zone were determined on carbon coated thin sections using a CAMECA model SX100 electron microprobe equipped with five wave dispersive spectrometers at the University of Montpellier. For phyllosilicates, the microprobe was operated at $20 \mathrm{kV}$, with a beam current of $10 \mathrm{nA}$ and a beam diameter of $3 \mu \mathrm{m}$. Standard deviations for all elements are better than $1 \%$. The standards for used for silicate analyses were albite $(\mathrm{Na}), \mathrm{Al}_{2} \mathrm{O}_{3}(\mathrm{Al})$, $\mathrm{Fe}_{2} \mathrm{O}_{3}(\mathrm{Fe})$, forsterite $(\mathrm{Mg})$, orthoclase $(\mathrm{K}), \mathrm{TiO}_{2}(\mathrm{Ti})$ and wollastonite ( $\mathrm{Si}, \mathrm{Ca}$ ) (for the choice of standards see Merlet and Bodinier, 1990).
In 7 thin sections, 35 analyses were obtained on phyllosilicates large enough for individual crystal analyses. The trace element contents ( $\mathrm{Fe}, \mathrm{Mg}, \mathrm{Mn}, \mathrm{Sr}$ ) of selected carbonates from veins were analysed using the same microprobe and same conditions, but with a beam diameter of $9 \mu \mathrm{m}$. The standards used were wollastonite (Ca), $\mathrm{Fe}_{2} \mathrm{O}_{3}(\mathrm{Fe})$, forsterite $(\mathrm{Mg})$, rhodochrosite $(\mathrm{Mn})$ and celestine ( $\mathrm{Sr}) .75$ analyses of calcite veins were performed.

\section{3. $X$-ray diffraction $(X R D)$}

For bulk XRD analyses, samples were grinded either by hand in an agate mortar or with a mechanical crusher. No significant differences in the results were observed between the two grinding modes. XRD analyses were recorded on 26 selected powders. Large enough samples were split up in order to duplicate the analyses. The sample Mi07-sp is composed of 7 sub-samples taken a few 
centimetres apart from each other across a highly deformed marl section bounded by two secondary shear zones. The 26 powders were analysed at the University of Franche-Comté (Besançon) using a Bruker D8 Advance diffractometer system using $\mathrm{Cu}-\mathrm{K} \alpha$ radiation equipped with a fast LynxEye linear detector. The diffractometer was operated at $40 \mathrm{kV}$ and $40 \mathrm{~mA}$; scans were run from $5^{\circ}$ to $120^{\circ} 2 \theta$, with a step interval of $0.02^{\circ} 2 \theta$ and a goniometry speed of $1 \mathrm{~s}$ per step.

The identification of all minerals was performed using BrukerAXS's DiffracPlus EVA software and the ICDD Powder Diffraction File 2008 database (The International Centre for Diffraction Data). Mineral quantification was made by Rietveld refinement (Rietveld, 1969) using the fundamental parameters (FP) approach (Cheary and Coelho, 1992) of the DIFFRACplus TOPAS software, version 4.2 (2009, Bruker AXS). The Rietveld method consists in minimising the difference between a diffractogram calculated for a given starting model and the experimental diffractogram. Minimisation is done by simultaneously adjusting instrumental and sample parameters by a non-linear multivariable least square procedure. Zero shift and sample displacement were the two instrumental parameter refined. In the FP approach the influence on intensity of other instrumental factors, such as diffraction aperture sizes, are calculated from first principles. The following sample parameters were refined: unit cell parameters, isotropic temperature factors, weight fractions of the phases present, coherent single scattering domain sizes and preferred orientation parameters (March Dollase model). Background intensities were fitted by a fifth order polynomial. The weight fraction of phase $i, W_{i}$, in a mixture of $N$ phases is obtained from the scale parameter $s_{j}$ (Hill and Howard, 1987):

$W_{i}=\left(s_{i}\left(Z_{i} M_{i} V_{i}\right)\right) /\left(\sum_{j=1}^{N} s_{j}\left(Z_{j} M_{j} V_{j}\right)\right)$

with $Z_{i}$ the number of formula units in the unit cell, $M_{i}$ and $V_{i}$ the mass respectively the unit cell volume of phase $i$. The scale factor $s$ normalises measured intensities (arbitrary units, i.e. X-ray counts) into electron (structure factor) units. Crystal structure data for albite, calcite, chlorite, illite and quartz were taken from the ICDD PDF and Bruker Structure Database. The polytypes of the two phyllosilicates were selected according to characteristic peaks (i.e. Moore and Reynolds, 1997). Considering the very small deviations from ideal stoichiometry, calcite, quartz, albite and illite reference data were used without modification. The site occupancies of the chlorite reference structure were adjusted according to microprobe analyses.

Weighted residuals of the whole pattern (Rwp) and the goodness of fit (GOF) were taken as fit criteria (Toby, 2006). Rwp and GOF values for the present refinements range from $4.84 \%$ to $6.26 \%$ and from $2.17 \%$ to $2.71 \%$ respectively. Estimated standard deviations (e.s.d.) given in Rietveld programs take only into account errors due to counting statistics but not systematic errors. They are indicating the precision but not the accuracy of the data. Only if the model is completely correct, which implies that any systematic error in the data must be appropriately described, least-squares error estimates are reliable indicators of accuracy (Post and Bish, 1989; Young, 1993). Preferred orientation and microabsorption are the main sources for systematic errors, which affect intensities and, therefore, the phase quantification. However, phyllosilicates have refined March-Dollase coefficients indicating a weak preferred orientation for these phases. Moreover, for diffraction experiments made with $\mathrm{CuK} \alpha$ radiation, microabsorption affects mainly iron containing phases. The Fe concentration in the chlorite phase, the most iron rich phase in the samples, is too low for microabsorption to have a significant impact. Previously published quantification of known mineral mixtures by Rietveld refinements have shown that the true concentration was within or very close to the estimated standard deviations of the refined concentrations (Liang and Hawthorne, 1994; Post and Bish, 1989). A conservative, though empirical approach (Taylor and Hinczak, 2003), is to multiply the e.s.d. values with the goodness of fit, a procedure applied to the results obtained in this study. Iterations were performed until the refinement converged. Convergence was achieved when all the parameter shifts $\Delta x_{i}$ calculated in three consecutive cycles satisfy the condition $\left|\Delta x_{i}\right|<a \sigma_{1}$ where $a$ is a user-defined value and $\sigma_{1}$ is the e.s.d. of the parameter $i$. In our study, the $a$ value was set to 0.001 .

\subsection{Bulk rock chemistry}

Major elements analyses of 3 host rock samples and of 5 deformed marls were carried out by X-ray Fluorescence Spectrometry (XRF) at the Centre d'Analyse Minérale (CAM) from the University of Lausanne. Bulk rock analyses were performed using a Philips PW2400 spectrometer equipped with a rhodium anode. Measurements were performed on melted tablets $4 \mathrm{~cm}$ in diameter, requiring $10-15 \mathrm{~g}$ of powdered rock. The detection limits are approximately $0.01 \%$. These analyses were conducted during the thesis of Lacroix (2011).

\subsection{Mass, volume and porosity measurements}

Water porosimetry measurements were performed on samples using the Archimedes' method to quantify their total porosity and their bulk density (Monicard, 1975; Zinszner and Pellerin, 2007). The samples were dried at $60{ }^{\circ} \mathrm{C}$ until they reached a stable mass $\left(m_{d}\right)$. They were then degassed during $24 \mathrm{~h}$ in an airtight enclosure before being progressively saturated, adding degassed and distilled water under a dynamic vacuum to the bottom of the samples. The total porosity $(\Phi)$ is given by the expression $\Phi=\left[\left(m_{1}-m_{d}\right) /\right.$ $\left.\left(m_{1}-m_{2}\right)\right] \times 100$, where $m_{1}$ is the mass of the sample fully saturated with a degassed and distilled water in vacuum, whereas $m_{2}$ is the mass of the same sample immersed in water (hydrostatic underwater weighing). The bulk density $(\rho)$ is given by the expression $\rho=m_{1} /\left(m_{1}-m_{2}\right)$. Density is accurate to \pm 0.005 and porosity to $\pm 0.05 \%$.

\section{Results and interpretation}

\subsection{Petrography, mineralogy and microstructures}

\subsubsection{Host rock}

The hanging wall and the footwall are composed of homogenous Millaris marls with a regular, semi-penetrative north-dipping cleavage oblique to bedding (Fig. 4A). The fine-grained matrix consists of detrital quartz, calcite and detrital clay grains with a size from 5 to $20 \mu \mathrm{m}$, and contains millimetric pyrite aggregates as well as bioclasts (Fig. 4A-C). The cleavage corresponds to discrete pressure solution surfaces (microstylolites) with a spacing of approximately $10 \mu \mathrm{m}$. The bioclasts form rigid objects disturbing the distribution and orientation of these pressure solution surfaces (Fig. 4B). Phyllosilicates are preferentially oriented (Fig. 4D) being often reoriented sub-parallel to the pressure solution surfaces (Fig. 4C).

XRD analyses of the host rock confirm the abundance of quartz and calcite as well as the presence of chlorite and illite (Fig. 5A). Bulk XRD patterns suggest that albite is present in small quantity.

Host rock samples Mi06-05, Mi07-02 and Mi07-03 (Table 1) have very similar chemical compositions with a mean composition of $\mathrm{CaO}=30.1 \mathrm{wt} \% ; \mathrm{SiO}_{2}=27.8 \mathrm{wt} \%$; volatiles $(\mathrm{LOI})=26.2 \mathrm{wt} \%$; 


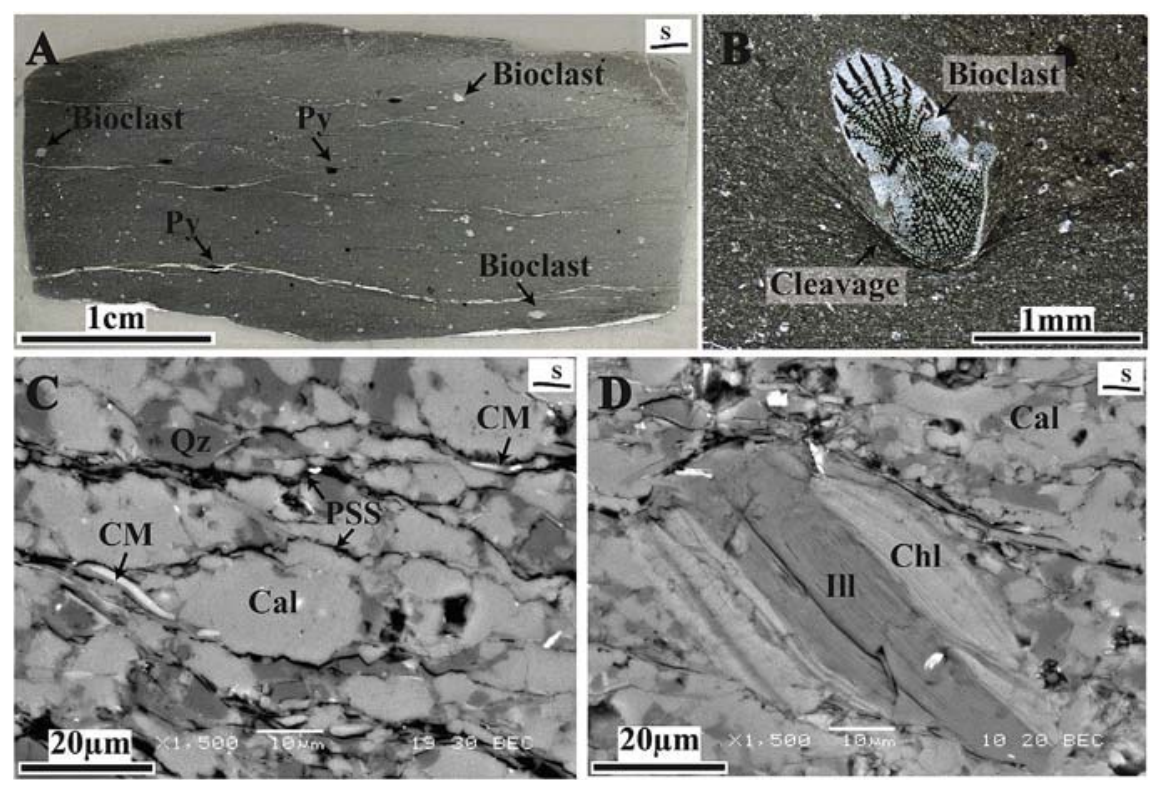

Figure 4. Hanging wall and footwall petrography. (A) Scanned image of Mi07-02II thin section showing matrix homogeneity and presence of cleavage. (B) Bioclast in homogenous matrix with development of pressure solution cleavage: SEM image from sample Mi07-02II. (C) Detrital quartz and calcite grains with detrital clay minerals of the matrix. Note the discrete pressure solution surfaces corresponding to the regional cleavage: SEM image from sample Mi07-02. (D) Chlorite-illite stack: SEM image from sample Mi07-02. Key: Cal: calcite; Chl: chlorite; CM: clay minerals; Ill: illite; PSS: pressure solution surface; Py: pyrite; Qz: quartz; S: cleavage.

$\mathrm{Al}_{2} \mathrm{O}_{3}=8.3 \mathrm{wt} \% ; \mathrm{Fe}_{2} \mathrm{O}_{3}=2.8 \mathrm{wt} \% ; \mathrm{MgO}=1.7 \mathrm{wt} \%$ and $\mathrm{K}_{2} \mathrm{O}=1.6 \mathrm{wt}$ \%. $\mathrm{TiO}_{2}, \mathrm{MnO}, \mathrm{Na}_{2} \mathrm{O}, \mathrm{P}_{2} \mathrm{O}_{5}$ and $\mathrm{SO}_{2}$ represent less than $1 \mathrm{wt} \%$.

The chemical composition of detrital illite was obtained from microprobe analyses. Results are homogeneous (Table 2).

\subsubsection{Fault zone petrography, mineralogy and microstructures}

The fault zone comprises 10 m thick intensely deformed marls featuring a well-developed S-C fabric (Fig. 6). Calcite-quartz shear veins are common along the shear surfaces from up to centimetrethick tabular bodies to microscopic shear veins, and extension veins cut the cleavage (Fig. 6A). The biggest veins were avoided during sampling to focus the analyses on the clay rich matrix. The latter is darker than the host rock marl and presents an intense, closelyspaced cleavage marked by clay minerals (Fig. 6B). Calcite is only present as veins or veinlets (Fig. 6C). Shear veins filled by chlorite are preferentially located at the proximity of calcite veins (Fig. 6C, D) and newly-formed chlorites are often associated with micas. The preferred orientation of chlorite particles and their location along shear veins suggest that they precipitated contemporaneously to the shear movement (Fig. 6D). Locally, in samples taken at the faulthost rock boundary, small newly-formed chlorite laths can be found around partially dissolved framboïdal pyrites (Fig. 6E).

XRD data (one example in Fig. 5B) confirm that samples from the fault zone and host rock have similar mineralogical assemblages, but in varying proportions. The relative proportion of calcite in the fault zone matrix is generally smaller than in the host rock samples. However, bulk chemistry of fault zone samples (Table 1) display strong variations, particularly in $\mathrm{CaO}$ which varies between 9 and $23 \mathrm{wt} \%$. The latter result can be explained by the occurrence of microscopic calcite veins in the studied samples. According to microprobe analyses, calcite veins display homogeneous composition and have a total $\mathrm{Mg}+\mathrm{Fe}+\mathrm{Mn}+\mathrm{Sr}$ content less than about $2 \mathrm{~mol} \%$. The median structural formula obtained from 75 analyses is given in Table 2. The low-Mg content points to a Mg-depleted marine basin water, i.e. diagenetically evolved seawater instead of unmodified seawater as precipitation environment (Boles et al., 2004).
The chlorite X-ray diffraction intensity $(I)$ ratio $[I(002)+I(004)] /$ $[I(001)+I(003)]$ (Table 3$)$ indicates a higher iron content in chlorites from the fault zone compared to chlorites from the host rocks (Brindley and Brown, 1980). These data suggest that two different chlorites occur in the studied samples: detrital chlorite, which is present in the host rock, and newly-formed synkinematic iron rich chlorite, which occurs in the fault zone.

Newly-formed chlorites identified by microscopy (optical and SEM) along shear veins were analysed by microprobe. They have intermediate chemical compositions between sudoite, amesite and 14 Ångstrom daphnite/clinochlore (Fig. 7A). The octahedral site is mainly constituted by $\mathrm{R}^{2+}$ cations $\left(\mathrm{Fe}^{2+}+\mathrm{Mg}^{2+}\right)$, iron prevailing (Fig. 7B). Si content varies from 2.68 to 2.95 a.p.f.u., $\mathrm{Al}^{\mathrm{IV}}$ from 1.05 to $1.32, \mathrm{Al}^{\mathrm{VI}}$ from 1.55 to $1.87, \mathrm{Mg}$ from 1.58 to 1.87 and Fe from 2.09 to 2.47 a.p.f.u.. The data dispersion is minimal and does not show any Tschermak, dioctahedral-trioctahedral or $\mathrm{Fe}-\mathrm{Mg}$ substitution. The median formula that can be calculated from 31 analyses is presented in Table 2.

Porosity has been calculated from mass and volume measurements on several samples (Table 4 ). The host rock porosity is $4.84 \%$ while it varies from 5.68 to $8.26 \%$ in the fault zone. Porosity in the fault zone is linked to cleavage. It might vary depending on the number of micro-veins, the intensity of cleavage and/or the heterogeneity of shear. We can suppose that the increase in porosity is linked to the decrease of calcite content in the fault zone, through to the development of microstructures like stylolites (Raynaud and Carrio-Schaffhauser, 1992) during fault deformation.

\subsection{Mineral quantification}

\subsubsection{Rietveld refinement}

The minerals present in the Millaris samples were determined by coupling two independent methods: XRD and microprobe data. Rietveld refinement has been performed with the Topas software on each bulk rock diffractogram in order to quantify the mineral proportions for hanging wall, footwall and fault zone samples. Calcite, quartz, $2 \mathrm{M}_{1}$ Illite, Chlorite IIb (with $\mathrm{Mg} /(\mathrm{Mg}+\mathrm{Fe}$ ) amount 

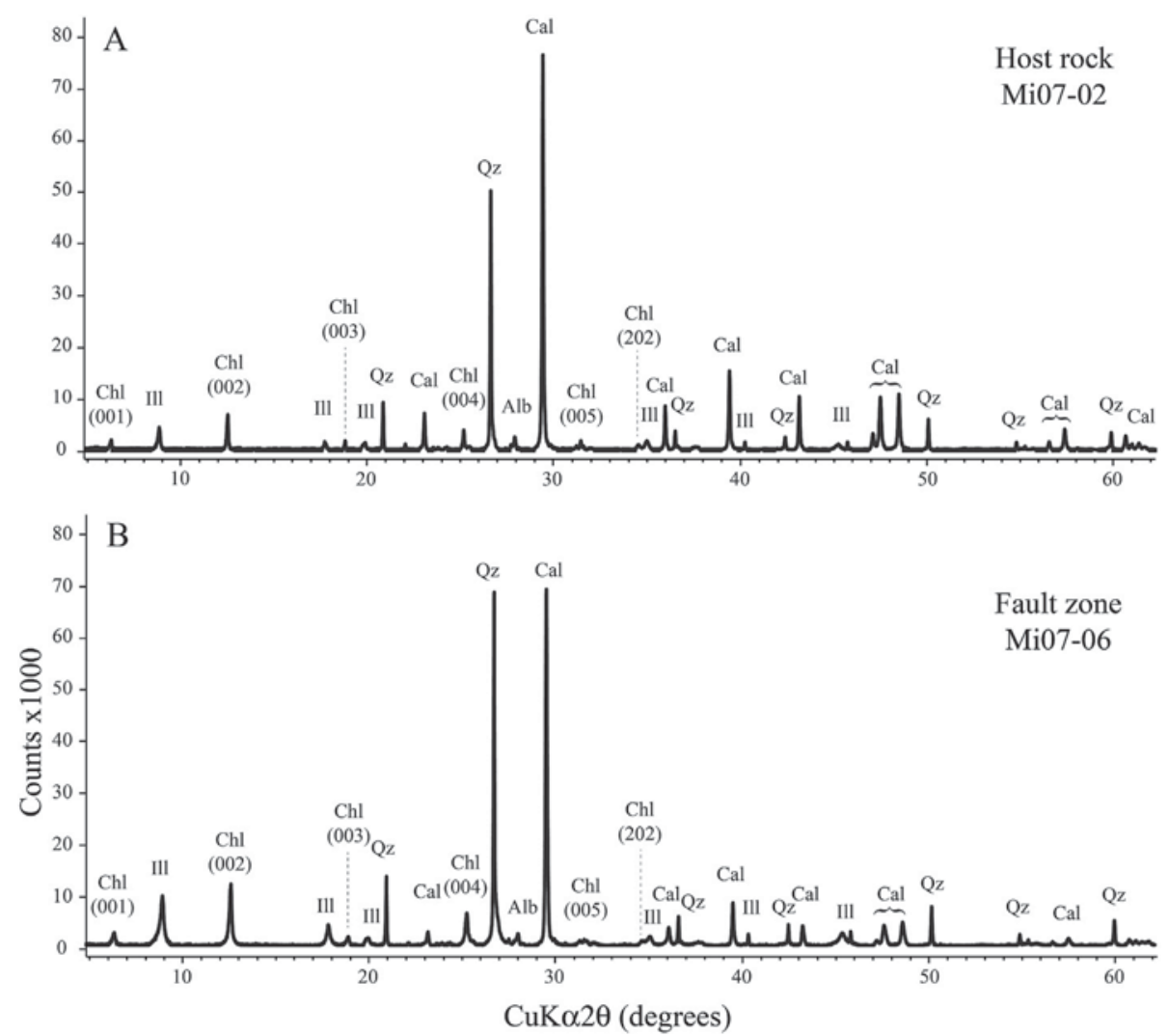

Figure 5. X-ray diffractograms obtained on bulk rock samples. Typical examples of X-ray diffractogram in host rock Mi07-02 sample (A) and in fault zone Mi07-06 sample (B). Key Alb: albite; Cal: calcite; Chl: chlorite; Ill: illite; Qz: quartz.

adjusted to 0.42 to fit the microprobe data) and albite have been chosen (Fig. 8). These analyses confirm the abundance of quartz, calcite and phyllosilicates.

The different host rock samples display very homogenous compositions. For example, in host rock Mi07-03B sample, calcite is the dominant mineral with about $57 \mathrm{wt} \%$, quartz represents $16 \%$, the phyllosilicates assemblage ( $23 \%$ tot.) is composed of $7 \%$ chlorite and $16 \% 2 \mathrm{M}_{1}$ illite, albite represents $3 \%$ (Table 3, Fig. 9). The mineral contents of the fault zone samples, however, are very variable (Table 3, Fig. 9). The heterogeneity is particularly visible on the 7 sub-samples labelled Mi07-Sp which were collected at regular intervals of few centimetres along a small transect within the fault zone (Fig. 3B) and show calcite content varying between 20 and $45 \mathrm{wt} \%$. The mineralogical heterogeneity can be explained by the presence of randomly distributed microscopic calcite veinlets in the deformed samples and/or by the presence of domains more affected by calcite pressure-solution than the adjacent domains. During sampling, centimetric veins were avoided but microscopic veins can be present in some samples. Considering all samples from the fault-zone, calcite varies from 17 to $48 \mathrm{wt} \%$, quartz from 17 to $31 \mathrm{wt} \%$, illite from 20 to $43 \mathrm{wt} \%$, chlorite from 7 to $12 \mathrm{wt} \%$. Albite is always less than $5 \mathrm{wt} \%$. The dispersion of data reflects the heterogeneity of the mineralogical composition of the fault rock that can be related to different degrees of deformation. For this reason, the mass balance calculation (Section 4.3) considered each fault zone sample separately.

\subsubsection{Normative mineralogy}

In sedimentary petrology, rock characterisation by normative mineralogical composition is not common. There have been only a few attempts using this procedure (Rosen et al., 2004 and references therein). A normative mineral assemblage can be calculated when the bulk chemical composition, the minerals present, that should produce the given chemical composition, and their chemical composition are known. In our case, the bulk chemical compositions were obtained by XRF data, the minerals were identified by XRD and the chemical composition of individual mineral phases (calcite, chlorite and illite) were calculated from microprobe analyses (see results above). The mineral structural formulas used are reported in Table 5A.

Calculated mineral proportions are presented in Table 5B. Host rock compositions are homogenous with an average composition of $55 \mathrm{wt} \%$ of calcite, $18 \mathrm{wt} \%$ of quartz, $17 \mathrm{wt} \%$ of illite, $9 \mathrm{wt} \%$ of chlorite and $1 \mathrm{wt} \%$ of albite. Apatite, rutile and pyrite together represent less than $1 \mathrm{wt} \%$ of the total weight. In the fault zone, calculated mineralogical compositions are more variable: 17 to $42 \mathrm{wt} \%$ of calcite, 22 to $33 \mathrm{wt} \%$ of quartz, 21 to $37 \mathrm{wt} \%$ of illite, 12 to $16 \mathrm{wt} \%$ of chlorite, less than $3 \mathrm{wt} \%$ of albite and less than $1 \mathrm{wt} \%$ of rutile, apatite and pyrite.

To compare results obtained by two independent methods, normative and Rietveld calculations, a linear regression through the data points was calculated (Fig. 10). $R^{2}=0.94$ shows that the results obtained by the two methods are close. We use, therefore, the Rietveld quantification results for the rest of the study.

\subsection{Mass transfer calculations}

Macro and microscopic observations indicate that the fault zone is well defined, bounded by two major shear surfaces (Fig. 3). The host rock is only affected by regional cleavage, much less intense than cleavage in the fault rock (e.g. compare Fig. 4C with Fig. 6B) and we assume that the mass transfer occurred only inside the fault 
Table 1

Chemical analyses in oxides weight percentages conducted on Millaris samples by X-ray fluorescence.

\begin{tabular}{|c|c|c|c|c|c|c|c|c|c|}
\hline & \multicolumn{4}{|l|}{ Host rock } & \multicolumn{5}{|l|}{ Fault zone } \\
\hline & Mi-06-05 & Mi-07-02 & Mi-07-03 & Mean & Mi-07-04 & Mi-07-05 & Mi-07-06 & Mi-07-07 & Mi-07-08 \\
\hline $\mathrm{SiO}_{2}$ & 26.25 & 29.68 & 27.36 & 27.76 & 38.85 & 35.19 & 52.14 & 41.45 & 45.49 \\
\hline $\mathrm{TiO}_{2}$ & 0.34 & 0.36 & 0.35 & 0.35 & 0.43 & 0.42 & 0.58 & 0.46 & 0.65 \\
\hline $\mathrm{Al}_{2} \mathrm{O}_{3}$ & 8.54 & 8.67 & 8.46 & 8.56 & 12.03 & 11.23 & 15.85 & 12.54 & 17.56 \\
\hline $\mathrm{Fe}_{2} \mathrm{O}_{3}$ & 2.84 & 2.80 & 3.24 & 2.96 & 4.16 & 3.61 & 4.03 & 3.94 & 5.31 \\
\hline $\mathrm{MnO}$ & 0.07 & 0.05 & 0.07 & 0.06 & 0.05 & 0.05 & 0.03 & 0.05 & 0.04 \\
\hline $\mathrm{MgO}$ & 1.48 & 1.63 & 1.48 & 1.53 & 1.72 & 1.58 & 1.73 & 1.64 & 2.16 \\
\hline $\mathrm{CaO}$ & 31.06 & 28.88 & 30.25 & 30.06 & 19.90 & 23.07 & 9.39 & 18.44 & 13.25 \\
\hline $\mathrm{Na}_{2} \mathrm{O}$ & 0.30 & 0.32 & 0.27 & 0.30 & 0.21 & 0.56 & 0.49 & 0.20 & 0.45 \\
\hline $\mathrm{K}_{2} \mathrm{O}$ & 1.61 & 1.66 & 1.60 & 1.62 & 2.38 & 2.01 & 3.35 & 2.49 & 3.61 \\
\hline $\mathrm{P}_{2} \mathrm{O}_{5}$ & 0.07 & 0.07 & 0.07 & 0.07 & 0.06 & 0.07 & 0.09 & 0.07 & 0.10 \\
\hline LOI & 26.80 & 25.17 & 26.11 & 26.03 & 19.28 & 21.44 & 11.63 & 18.09 & 10.53 \\
\hline $\mathrm{SO}_{2}$ & 0.02 & 0.02 & 0.02 & 0.02 & 0.07 & 0.05 & 0.05 & 0.05 & 0.05 \\
\hline$\sum$ & 99.38 & 99.31 & 99.28 & 99.32 & 99.14 & 99.28 & 99.36 & 99.42 & 99.2 \\
\hline
\end{tabular}

zone. Therefore, assuming that both the host and fault rocks derive from a common protolith, we compare host rock and fault zone sample analyses in order to quantify the mass transfer and volume change related to deformation and fluid rock interaction induced by fault activation.

Mass balance calculations have been performed to quantify chemical mass transfers occurring during reactions in the fault zone. The mass balance calculation approach is based on Gresens' equation (Gresens, 1967):

Table 2

Microprobe data of chlorite, illite and calcite from Millaris samples. Median compositions from number $n$ analyses were calculated. $\mathrm{X}_{\mathrm{Mg}}: \mathrm{Mg} /(\mathrm{Fe}+\mathrm{Mg})$ amount; $\sigma$ : standard deviation.

\begin{tabular}{|c|c|c|c|c|}
\hline A & Illite $(n=3)$ & $\sigma$ & Chlorite $(n=31)$ & $\sigma$ \\
\hline $\mathrm{SiO}_{2}$ & 47.1 & 0.2 & 25.82 & 0.9 \\
\hline $\mathrm{TiO}_{2}$ & 0.38 & 0.2 & 0.02 & $<0.1$ \\
\hline $\mathrm{Al}_{2} \mathrm{O}_{3}$ & 34.9 & 0.9 & 23.15 & 0.6 \\
\hline $\mathrm{FeO}$ & 1.63 & 0.6 & 26.98 & 0.9 \\
\hline $\mathrm{MgO}$ & 1.14 & 0.3 & 11.01 & 0.5 \\
\hline $\mathrm{CaO}$ & 0.21 & $<0.1$ & 0.27 & 0.1 \\
\hline $\mathrm{Na}_{2} \mathrm{O}$ & 0.87 & 0.2 & 0.02 & $<0.1$ \\
\hline $\mathrm{K}_{2} \mathrm{O}$ & 10.3 & 0.6 & 0.05 & 0.1 \\
\hline$\sum$ & 96.5 & 0.7 & 87.32 & 1.1 \\
\hline Oxygen & 11 & & 14 & \\
\hline $\mathrm{Si}$ & 3.1 & $<0.1$ & 2.75 & 0.1 \\
\hline $\mathrm{Al}^{\mathrm{IV}}$ & 0.9 & $<0.1$ & 1.25 & 0.1 \\
\hline $\mathrm{Al}^{\mathrm{VI}}$ & 1.81 & 0.1 & 1.63 & 0.1 \\
\hline $\mathrm{Fe}^{2+}$ & 0.09 & $<0.1$ & 2.4 & 0.1 \\
\hline $\mathrm{Mg}$ & 0.11 & $<0.1$ & 1.74 & 0.1 \\
\hline soct & 2.01 & & 5.77 & \\
\hline $\mathrm{Ca}$ & 0.01 & $<0.1$ & 0.03 & $<0.1$ \\
\hline $\mathrm{Na}$ & 0.11 & $<0.1$ & 0 & $<0.1$ \\
\hline $\mathrm{K}$ & 0.86 & 0.1 & 0.01 & $<0.1$ \\
\hline sint & 0.98 & & & \\
\hline $\mathrm{X}_{\mathrm{Mg}}$ & 0.56 & 0.1 & 0.42 & 0.1 \\
\hline B & \multicolumn{3}{|c|}{ Calcite $(n=70)$} & $\sigma$ \\
\hline $\mathrm{FeO}$ & \multicolumn{3}{|c|}{0.73} & 0.21 \\
\hline $\mathrm{MnO}$ & \multicolumn{3}{|c|}{0.11} & 0.03 \\
\hline $\mathrm{MgO}$ & \multicolumn{3}{|c|}{0.32} & 0.01 \\
\hline SrO & \multicolumn{3}{|c|}{0.05} & 0.06 \\
\hline $\mathrm{CaO}$ & \multicolumn{3}{|c|}{53.74} & 0.68 \\
\hline$\sum$ & \multicolumn{3}{|c|}{54.98} & 0.5 \\
\hline Oxygen & \multicolumn{3}{|c|}{3} & \\
\hline $\mathrm{Fe}$ & \multicolumn{3}{|c|}{0.01} & $<0.1$ \\
\hline $\mathrm{Mg}$ & \multicolumn{3}{|c|}{0.008} & $<0.1$ \\
\hline $\mathrm{Mn}$ & \multicolumn{3}{|c|}{0.002} & $<0.1$ \\
\hline $\mathrm{Sr}$ & \multicolumn{3}{|c|}{ bdl } & $<0.1$ \\
\hline $\mathrm{Ca}$ & \multicolumn{3}{|c|}{0.968} & 0.01 \\
\hline
\end{tabular}

$\Delta C_{i}=\left(M^{\mathrm{FZ}} / M^{\mathrm{P}}\right) * C_{i}^{\mathrm{FZ}}-C_{i}^{\mathrm{P}}$

where $C_{i}$ : concentration of element $i$; $M$ : mass, with $M=V \rho, V$ : volume and $\rho$ : density. "P" refers to the protolith and "FZ" to the fault zone samples so $M^{\mathrm{P}}$ and $M^{\mathrm{FZ}}$ are masses before and after deformation. Masses and volumes have been measured for five samples: one from the host rock and four from the fault zone (Table 4). Densities and porosities have been calculated from these mass and volume measurements.

Among the different possible approaches (e.g. Baumgartner and Olsen, 1995; Grant (1986); Potdevin and Marquer, 1987), we used the Isocon method from Grant (1986), as it is best adapted to our study case, i.e. to compare the initial state before deformation (by faulting episode) represented by host rock samples with fault zone samples and to discuss the mobility of chemical elements and the scale of mass transfers by fluids. Grant (1986) proposed to use an Isocon diagram to facilitate the reading of the mass balance equation. In order to do this, the Gresens equation was rearranged into a linear relationship between the concentration of an element in a fault zone sample and the concentration of the same element in a protolith sample.

$C_{i}^{\mathrm{FZ}}=\left(M^{\mathrm{P}} / M^{\mathrm{FZ}}\right) *\left(C_{i}^{\mathrm{P}}-\Delta C_{i}\right)$

For immobile elements, which show no gain or loss of mass $\left(\Delta C_{i}=0\right)$, the equation becomes:

$C_{i}^{\mathrm{FZ}}=\left(M^{\mathrm{P}} / M^{\mathrm{FZ}}\right) * C_{i}^{\mathrm{P}}$

This equation characterises the "isocon". Immobile elements such as aluminium are used to define the isocon e.g. the ratio $\left(M^{\mathrm{P}} /\right.$ $\left.M^{\mathrm{FZ}}\right)$. The isocon is represented by a straight line with slope $\left(M^{\mathrm{P}} /\right.$ $M^{\mathrm{FZ}}$ ) in the diagram. The element concentrations of a fault zone samples $\left(C_{i}^{\mathrm{A}}\right)$ are then plotted against element concentrations of the protolith samples $\left(C_{i}^{0}\right)$. Chemical elements, which plot below the isocon, left the system whereas chemical elements, which plot above the isocon, entered into the system.

Chemical compositions (s. Table 1) of each fault zone sample are reported as a function of the calculated mean host rock chemical composition. Figure 11 illustrates results obtained from samples Mi07-06 and Mi07-05, which are thought to represent the most deformed and less deformed fault zone samples, respectively.

For each sample the dotted line in the diagram corresponds to the isocon based on the aluminium concentrations including the origin. For all fault zone sample (Mi07-05, Mi07-06 as well as the others), $\mathrm{Ti}, \mathrm{Si}, \mathrm{K}, \mathrm{Na}$ in addition to $\mathrm{Al}$ are immobile. $\mathrm{Ca}$ as well as the volatiles (mass obtained from loss of ignition and mainly 

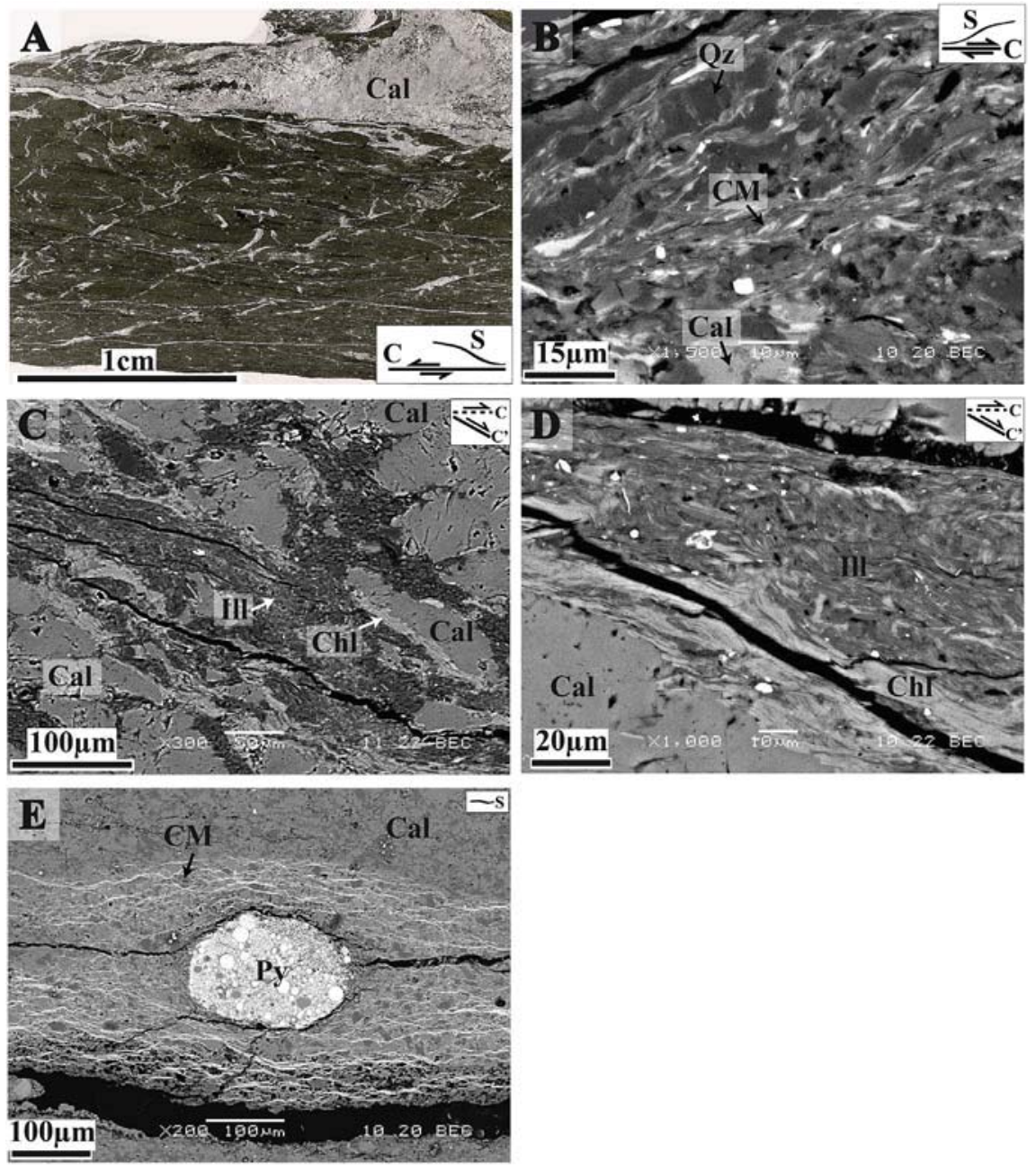

Figure 6. Fault zone microstructure. (A) Scanned image of Mi07-06II thin section: general view of the heterogeneous fault rock comprising argillaceous foliated matrix and shear and extension calcite veins; note the S-C fabric with S: cleavage surfaces and C: shear surfaces. (B) SEM images from fault zone Mi07-05 sample: quartz-argillaceous matrix having an intense S-C fabric corresponding to a closely-spaced cleavage underlain by clay minerals. (C) SEM image from Mi07-04 sample: calcite veins with development of chlorite in contact with matrix. (D) SEM images from Mi07-04II sample: idem as (C), detail view. (E) SEM images from Mi07-05 sample located at the fault-host rock boundary: framboïdal pyrite with development of clay minerals. Key: Cal: calcite; Chl: chlorite; CM: clay minerals; Ill: illite; Py: pyrite; Qz: quartz.

corresponding to $\mathrm{CO}_{2}$ ) are highly depleted, the depletion being extreme in sample Mi07-06. $\mathrm{Mg}$ is also slightly depleted in both samples. Iron is depleted only in a few samples.

The change in volume can be calculated for each sample, using the density values and the $\left(M^{\mathrm{FZ}} / M^{\mathrm{P}}\right)$ ratio corresponding to the isocon:

$\Delta V=\left(V^{\mathrm{FZ}} / V^{\mathrm{P}}\right)=\left(M^{\mathrm{FZ}} / M^{\mathrm{P}}\right) *\left(\rho^{\mathrm{FZ}} / \rho^{\mathrm{P}}\right)$

with $\rho$ : measured rock density (see Table 4).

According to equation (5), we estimated that sample Mi07-06 suffered a volume loss of $46 \% \pm 1 \%$ mostly due to a loss of $\mathrm{CaO}$ (25 wt $\% \pm 1 \%$ ) and $\mathrm{CO}_{2}(20 \mathrm{wt} \% \pm 1 \%)$. Uncertainties were calculated by integrating the chemical heterogeneity of the protolith, the analytical error was not taken into account because negligible relative to the heterogeneity. The loss in $\mathrm{CaO}(12.5 \mathrm{wt} \% \pm 1 \%)$ and $\mathrm{CO}_{2}(10 \mathrm{wt} \% \pm 1 \%)$ in sample Mi07-05 correspond to a volume loss of $21 \% \pm 1 \%$.

In order to quantify the behaviour of mineralogical phases during deformation, we plotted the mineralogical concentrations of the same samples, Mi07-05 and Mi07-06 obtained from Rietveld refinement in an isocon diagram (Fig. 12). The dotted line on this diagram corresponds to the isocon calculated from the mass ratio $\left(M^{\mathrm{FZ}} / M^{\mathrm{P}}\right)$ determined in Figure 11. An important depletion in calcite and a slight increase in the amount of illite can be noticed. The concentrations of the other minerals are stable. These variations are highlighted in Figure 13. One can see a significant loss of calcite for all samples, from 22 to $47 \mathrm{wt} \%$, a gain of illite (up to $7 \mathrm{wt} \%$ ) and a small loss of chlorite (1-3 wt\%). Quartz is immobile for all samples except for sample Mi07-08. Albite concentration is very low, mass variations are of the same order as the uncertainty of the measurements; it is therefore not possible to affirm any mass variation trend for albite.

\section{Discussion}

\subsection{Transfers in the Millaris fault zone}

During fault activity, modifications of the chemistry and the mineralogy may occur in the core zone. They can be related to fluid circulations with fluid-rock interactions. Therefore, a quantitative approach of the mass transfer related to deformation can be useful to track the origin of chemical and mineralogical modifications.

Based on Gresens works (Gresens, 1967), Grant (1986), Potdevin and Marquer (1987) and Baumgartner and Olsen (1995) developed 
Table 3

Proportions of minerals given by Topas software Rietveld refinement from XRD analyses. GOF: goodness of fit in percent. Rwp: weighted residual percent. Standard deviation was given by Topas software and needs to be multiplied by GOF to have a real approximation (see 3.3. X-ray diffraction section).

\begin{tabular}{|c|c|c|c|c|c|c|c|c|c|}
\hline Sample & Albite & Calcite & Chlorite & Illite & Quartz & Rwp & GOF & $\begin{array}{l}{[I(002)+I(004)] /} \\
{[I(001)+I(003)]}\end{array}$ & \\
\hline Mi-06-05 & $3.15 \pm 0.15$ & $55.65 \pm 0.37$ & $7.71 \pm 0.25$ & $18.91 \pm 0.45$ & $14.6 \pm 0.16$ & 5.97 & 2.43 & 3.00 & Host rock \\
\hline Mi-06-05B & $3.46 \pm 0.15$ & $59.26 \pm 0.49$ & $7.73 \pm 0.29$ & $14.7 \pm 0.62$ & $14.85 \pm 0.18$ & 5.70 & 2.36 & 3.24 & \\
\hline Mi-07-03 & $3.03 \pm 0.13$ & $57.98 \pm 0.35$ & $6.75 \pm 0.22$ & $16.93 \pm 0.42$ & $15.32 \pm 0.15$ & 5.77 & 2.32 & 2.65 & \\
\hline Mi-07-03B & $3.33 \pm 0.13$ & $57.17 \pm 0.39$ & $7.74 \pm 0.25$ & $15.82 \pm 0.49$ & $15.94 \pm 0.16$ & 5.16 & 2.18 & 2.58 & \\
\hline Mi-07-02 & $3.46 \pm 0.15$ & $51.81 \pm 0.34$ & $7.84 \pm 0.24$ & $18.08 \pm 0.45$ & $18.81 \pm 0.17$ & 5.72 & 2.30 & 2.64 & \\
\hline Mi-07-02B & $3.06 \pm 0.15$ & $55.93 \pm 0.46$ & $7.45 \pm 0.27$ & $15.59 \pm 0.6$ & $17.96 \pm 0.2$ & 5.59 & 2.32 & 2.43 & \\
\hline Mi-06-04 & $4.04 \pm 0.17$ & $27.74 \pm 0.29$ & $7.64 \pm 0.27$ & $38.93 \pm 0.52$ & $21.66 \pm 0.24$ & 5.79 & 2.64 & 3.49 & Fault zone \\
\hline Mi-07-08 & $2.73 \pm 0.19$ & $40.26 \pm 0.46$ & $8.24 \pm 0.34$ & $30.04 \pm 0.68$ & $18.72 \pm 0.26$ & 6.26 & 2.71 & 4.55 & \\
\hline Mi-07-08B & $3.72 \pm 0.16$ & $25.5 \pm 0.25$ & $11.07 \pm 0.3$ & $40.25 \pm 0.45$ & $19.47 \pm 0.2$ & 4.84 & 2.36 & 3.24 & \\
\hline Mi-07-07 & $5.24 \pm 0.16$ & $26.77 \pm 0.27$ & $7.66 \pm 0.27$ & $33.86 \pm 0.5$ & $26.46 \pm 0.25$ & 5.44 & 2.48 & 3.35 & \\
\hline Mi-07-07B & $2.08 \pm 0.14$ & $36.38 \pm 0.34$ & $9.63 \pm 0.32$ & $26.58 \pm 0.57$ & $25.33 \pm 0.25$ & 4.86 & 2.17 & 2.39 & \\
\hline Mi-06-03 & $3.65 \pm 0.16$ & $26.88 \pm 0.27$ & $11.41 \pm 0.3$ & $29.14 \pm 0.55$ & $28.99 \pm 0.27$ & 4.92 & 2.26 & 3.87 & \\
\hline Mi-07-06 & $3.81 \pm 0.15$ & $20.56 \pm 0.22$ & $7.63 \pm 0.27$ & $39.35 \pm 0.45$ & $28.66 \pm 0.25$ & 5.13 & 2.36 & 4.10 & \\
\hline Mi07-06B & $3.97 \pm 0.15$ & $17.04 \pm 0.21$ & $9.51 \pm 0.31$ & $38.66 \pm 0.49$ & $31.05 \pm 0.29$ & 5.09 & 2.45 & 4.79 & \\
\hline Mi-07-05 & $4.08 \pm 0.17$ & $42.49 \pm 0.44$ & $7.78 \pm 0.29$ & $28.53 \pm 0.66$ & $17.12 \pm 0.22$ & 5.51 & 2.38 & 3.66 & \\
\hline Mi-07-05B & $5.35 \pm 0.14$ & $48.14 \pm 0.37$ & $8.01 \pm 0.28$ & $19.73 \pm 0.52$ & $18.77 \pm 0.18$ & 5.02 & 2.24 & 3.94 & \\
\hline Mi-07-04 & $1.74 \pm 0.14$ & $25.4 \pm 0.26$ & $8.83 \pm 0.29$ & $38.9 \pm 0.5$ & $25.13 \pm 0.25$ & 5.13 & 2.35 & 4.21 & \\
\hline Mi-07-04B & $1.97 \pm 0.16$ & $37.59 \pm 0.39$ & $9.97 \pm 0.35$ & $27.59 \pm 0.63$ & $22.88 \pm 0.26$ & 5.52 & 2.55 & 3.77 & \\
\hline Mi-07-sp1 & $2.64 \pm 0.15$ & $39.46 \pm 0.38$ & $9.24 \pm 0.33$ & $24.62 \pm 0.61$ & $24.05 \pm 0.25$ & 5.32 & 2.24 & 4.58 & \\
\hline Mi-07-sp2 & $2.72 \pm 0.16$ & $31.18 \pm 0.3$ & $11.5 \pm 0.3$ & $36.57 \pm 0.51$ & $18.02 \pm 0.21$ & 5.02 & 2.27 & 4.15 & \\
\hline Mi-07-sp3 & $3.87 \pm 0.18$ & $17.87 \pm 0.25$ & $12.28 \pm 0.35$ & $40.48 \pm 0.55$ & $25.51 \pm 0.29$ & 5.06 & 2.29 & 4.52 & \\
\hline Mi-07-sp4 & $2.49 \pm 0.16$ & $33.09 \pm 0.37$ & $10.27 \pm 0.34$ & $33.96 \pm 0.64$ & $20.19 \pm 0.25$ & 5.41 & 2.38 & 4.63 & \\
\hline Mi-07-sp5 & $3.17 \pm 0.16$ & $41.29 \pm 0.39$ & $9.86 \pm 0.32$ & $23.86 \pm 0.61$ & $21.83 \pm 0.32$ & 5.51 & 2.46 & 3.64 & \\
\hline Mi-07-sp6 & $5.43 \pm 0.15$ & $46.39 \pm 0.4$ & $7.84 \pm 0.29$ & $21.16 \pm 0.59$ & $19.18 \pm 0.2$ & 5.23 & 2.25 & 3.19 & \\
\hline Mi-07-sp7 & $3.41 \pm 0.17$ & $24.79 \pm 0.28$ & $9.2 \pm 0.32$ & $43.11 \pm 0.53$ & $19.48 \pm 0.24$ & 5.40 & 2.48 & 3.82 & \\
\hline $\mathrm{Mi}-06-02$ & $0 \pm 0.13$ & $36.37 \pm 0.32$ & $6.86 \pm 0.23$ & $27.42 \pm 0.52$ & $29.35 \pm 0.27$ & 6.26 & 2.62 & 3.10 & \\
\hline
\end{tabular}

mass balance calculation approaches. This method has been applied to a wide range of geological processes (see examples in Grant, 2005). In the case of fault zones, changes between fault zones and less deformed wall rocks were interpreted either as (1) volume loss within the fault zone: as outlined by numerous authors (e.g. Demény et al., 1997; Dickin, 1988; Lonka et al., 1998; O’Hara, 1988), fault zones commonly show increasing contents of relatively immobile elements suggesting a volume loss that can be explained as the result of depletion of other more soluble elements during deformation, (2) volume gain during deformation: this case corresponds to a high activity of metamorphic fluids which change the rates of chemical and mechanical processes (e.g. Hippertt, 1998; Selverstone et al., 1991), (3) isochoric (constant volume) deformation: in this case, the activity of internal fluids may cause mineral reactions but no change in bulk volume nor chemistry (e.g. Steyrer and Sturm, 2002). However, most examples given so far in the literature are related to deformation of magmatic and metamorphic rocks. In sedimentary environments, the heterogeneity of the host rock is often strong limiting the possibility of quantification.

In the present study, we consider the Millaris fault zone to be an ideal area to study mass transfer through a fault in a sedimentary context: the fault affects homogeneous marls, present in the footwall and in the hanging wall with very constant proportions of the main minerals, quartz, calcite and phyllosilicates (chlorite and illite). We therefore compare the host marls and the fault zone to quantify mass transfer related to deformation (by faulting episode), assuming that most of the transfers occur in the fault zone.

According to mass balance calculations, the present study reveals that most elements were immobile during deformation along the fault zone, with the exception of calcium and volatiles, which display significant loss during deformation. This result confirms our observations in thin sections: micritic calcite is present in the matrix of the marls whereas it is rare in the highly deformed sediments of the fault zone. These data show that the volume reduction (estimated between 20 and 45\%) was mainly accommodated by transfer of calcite from the matrix to the veins. However, at the fault zone scale, we can imagine the deformation as isochoric as calcite precipitated in calcite veins inside or at the boundaries of the fault zone. Those results would be in agreement with Lacroix et al.'s (2011) oxygen and carbon isotope data for calcite, which suggest strong fluid sediment interaction associated to deformation, with fluid chemistry buffered by host sediments without large scale fluid flow.

\subsection{Mineralogical reactions}

Quantifying the mineral content in sedimentary rocks is difficult because of the small size and the large variety of minerals. Two independent methods were used here, Rietveld refinement, and bulk chemical analyses coupled with microprobe analyses. The very good correlation between results obtained by both methods allows us to be confident about the mineral proportions estimates and to use the data to infer possible mineral reactions as calcite dissolution and phyllosilicates recrystallisations.

\subsubsection{Calcite}

The application of the isocon calculations to the mineralogical compositions obtained by Rietveld analyses confirms the major removal of calcite from the sediment matrix. On the other hand, $\mathrm{cm}$-thick calcite veins are present at the boundaries of the fault zone and calcite veinlets are numerous inside the highly deformed sediments. These observations suggest that pressure solution is the major mechanism of deformation responsible for the departure of calcite from the matrix and its precipitation in extension and shear veins. This is in agreement with the result from the isocon calculation that calcium and magnesium are highly mobile, whereas other elements are immobile such as silicon, iron and titanium (assuming aluminium as immobile for calculations). This is also consistent with the study of Lacroix et al. (2011) where they showed that the isotopic composition of the protolith calcite was similar to those of the veins. 


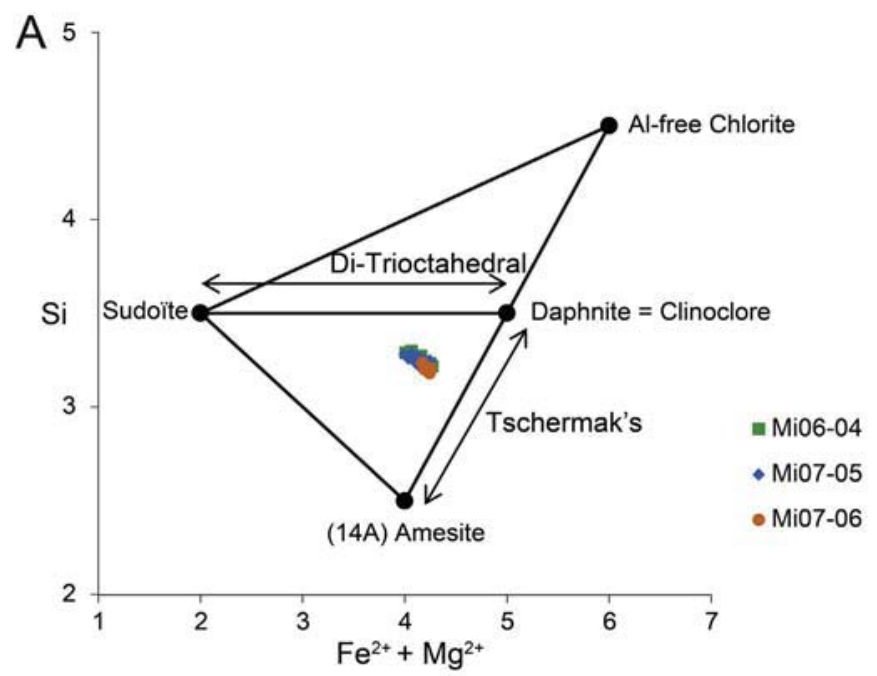

Perdido (Torla) fault zone suggest a stronger accumulation of deformation than in the Millaris fault zone (Lacroix et al., 2011; Buatier et al., 2012).

The newly-formed chlorites in the fault zone are iron-rich chlorites, close to the 14 Ångstrom daphnite end-member. Unfortunately, detrital chlorite particles from the host rock are too small to be analysed by microprobe. Nevertheless, the ratio $[I(002)+I(004)] /[I(001)+I(003)]$ calculated from peak heights measured in the XRD spectra (Table 3 ) is lower in protolith than in fault zone samples. These data suggest that newly-formed chlorites have higher Fe content than the detrital ones (Brindley and Brown, 1980).

As shown by many authors, in diagenesis to low grade metamorphism context the chemical composition of chlorite depends on bulk-rock composition, temperature, and pressure (e.g. De Caritat et al., 1993; and references therein; Zane et al., 1998). Oxygen fugacity variations might also yield to various chlorite Fe:Mg ratio for bulk-rock, temperature and pressure constant. Fe chlorite formation probably needs a lower oxygen fugacity condition than Mg chlorite (De Caritat et al., 1993), even if the precipitation of ironrich chlorites implies a still reductive environment (Dideriksen et al., 2007).

From these observations, we can assume that newly-formed chlorites incorporated iron. A source of iron could be the alteration of pyrite. Iron-oxide is the most common product of pyrite alteration, but transformation of pyrite into clay minerals has also been described by Charpentier et al. (2011). The clay mineral product was an iron-rich smectite and is explained by immediate buffering of acidity. In our case, acidity may immediately be neutralised by the strong buffering effect of calcite (Tabelin et al., 2012), which allow iron rich chlorites growth in neutral to basic or alkaline required conditions (Andrieux and Petit, 2010; Turner and Fishman, 1991).

Total illite content slightly increases in the fault zone. During diagenesis and low grade metamorphism, transformation of $\mathrm{K}$ feldspar to illite is common; this reaction requires fluid-rock interaction which can be enhanced in fault zone (e.g. Leclère et al., 2012). Haines and van der Pluijm (2012) showed the precipitation of $1 \mathrm{M}_{\mathrm{d}}$ illite in fault gouges at low temperature. According to these authors, $1 \mathrm{M}_{\mathrm{d}}$ illite occurrence is indicative of fault activity at temperature $<180{ }^{\circ} \mathrm{C}$ whereas $2 \mathrm{M}_{1}$ illite has a detrital origin. In the studied area, burial and fault activity yield to the formation of $2 \mathrm{M}_{1}$ illite polytype because temperature reached $240{ }^{\circ} \mathrm{C}$ (Buatier et al., 2012; Lacroix et al., 2011). Indeed the sequence $1 \mathrm{M}_{\mathrm{d}} \rightarrow 1 \mathrm{M} \rightarrow$ $2 \mathrm{M}$ is well known as indicator in increasing grade of diagenesis and low grade metamorphism (e.g. Hunziker et al., 1986; Maxwell and Hower, 1967; Yoder and Eugster, 1955).

K-feldspar, a common illite precursor, is absent the Millaris marl. Illitization of Na-feldspar under diagenetic conditions was shown in experiments and simulations with albite (Hellmann et al., 2010; Huang, 1992). Huang et al. (1986) succeeded in synthesising illite from albite, using $\mathrm{KCl}$ rich fluids.

In Millaris marls, the slight increase of illite in the fault zone could be linked to the transformation of detrital illite, associated with albite dissolution. Such reaction does not imply significant chemical transfer (only a little K gain which may be from the fluid or from illites recrystallisation). Unfortunately, albite concentration is too low to reliably determine concentration variations by Rietveld method and the variation in quartz is within the uncertainty of the method.

These data show that in the Millaris fault zone, clay minerals do not behaved as passive and insoluble minerals but underwent reactions and recrystallisation processes. Such reactions did not imply significant chemical transfer, suggesting local chemical changes. However, calcite dissolution and clay minerals 
Table 4

Densities and porosities measured using Archimedes method. Key: $m_{d}$ : mass of the dry sample; $m_{1}$ : mass of the sample fully saturated with a degassed and distilled water in vacuum; $m_{2}$ : mass of the same sample immersed in water (hydrostatic underwater weighing).

\begin{tabular}{lrrrlll}
\hline Sample & $m_{d}(\mathrm{~g})$ & $m_{1}(\mathrm{~g})$ & $m_{2}(\mathrm{~g})$ & $\begin{array}{l}\text { Bulk } \\
\text { density } \rho\end{array}$ & $\begin{array}{l}\text { Total } \\
\text { porosity } \Phi(\%)\end{array}$ \\
\hline Mi07-03 & 196.84 & 125.05 & 200.46 & 2.610 & 4.84 & Host rock \\
Mi07-04 & 223.13 & 142.28 & 229.17 & 2.567 & 7.04 & Fault zone \\
Mi07-05 & 115.53 & 73.60 & 119.25 & 2.530 & 8.26 & Fault zone \\
Mi07-06 & 34.90 & 22.23 & 35.66 & 2.594 & 6.11 & Fault zone \\
Mi07-07 & 83.52 & 53.26 & 85.30 & 2.605 & 5.68 & Fault zone \\
\hline
\end{tabular}

precipitation and reorganisation induced modifications of the rock properties, as shown in Figure 14. The dissolution of calcite during deformation led to a relative increase in quartz and phyllosilicates (Fig. 14B) and a higher rock porosity. With increasing deformation, there was a reorientation and crystallisation of clay minerals (Fig. 14C) as shown in the Torla fault (Buatier et al., 2012). As described by many authors in low-grade metamorphic rocks (e.g. Cavailhes et al., 2013; Faulkner and Rutter, 1998; Leclère et al., 2012), an increase of phyllosilicates concentration along the $S-C$ structures yields an increase in permeability of the rock. Indeed, the preferential orientation of phyllosilicates results in a preferential fluid-flow direction along the (001) basal planes parallel to the shear surfaces. Furthermore, the abundance of clay in a fault zone can influence fault slip as shown in the case of the Torla fault (Buatier et al., 2012; Lacroix et al., 2013). Numelin et al. (2007) have
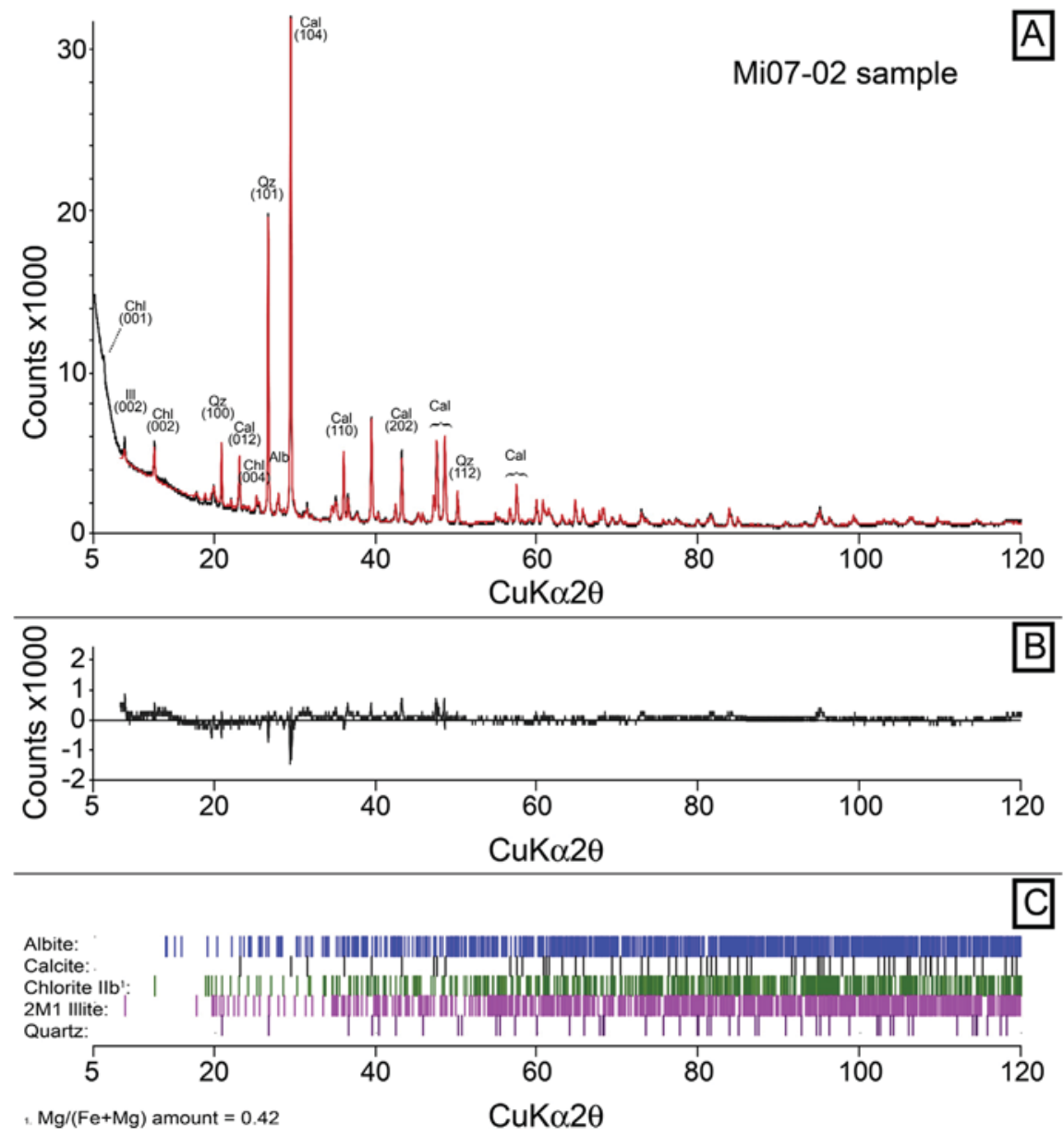

Figure 8. Rietveld refinement diffractograms of representative hanging wall bulk powered sample. (A) Observed and Topas software calculated XRD traces from host rock sample Mi07-02. (B) Difference between observed and calculated XRD diffractograms (in A). (C) Minerals XRD peak indexation used for Rietveld refinement. demonstrated a relationship between the amount of clay in a natural fault gouge and the frictional strength. The friction coefficient is $0.6-0.7$ for most rocks with low clay content (Byerlee, 1978), but may decrease to $0.2-0.4$ when rocks contain more than $50 \%$ of clays (Carpenter et al., 2011; Numelin et al., 2007), which is the case for friction coefficient of phyllosilicates (Behnsen and Faulkner, 2012).

\section{Conclusions}

Using a detailed mineralogical study combined with geochemtransfers and determined changes in the mineral assemblages in the studied fault zone during deformation. This study demonstrates that mass balance calculation can be an accurate method to investigate mass transfer and to quantify chemical and mineralogical changes related to deformation and fluid-rock interactions in a major thrust fault affecting sediments in diagenetic to low grade metamorphic conditions.

The studied fault zone is made of $10 \mathrm{~m}$ thick intensely deformed marls. The matrix presents an intense cleavage marked by phyllosilicates (illite and chlorite). Calcite is only present in veins or veinlets. Shear veins filled by chlorite are preferentially located at the proximity of calcite veins. The preferred orientation of chlorite particles suggests that they crystallised contemporaneously to the shear movement. Considering the small size of minerals in these fine-grained
sedimentary rocks, the Rietveld method is the method of choice most samples of the Millaris fault zone. This is due to the low ical analyses, we have quantified and characterised the mass 


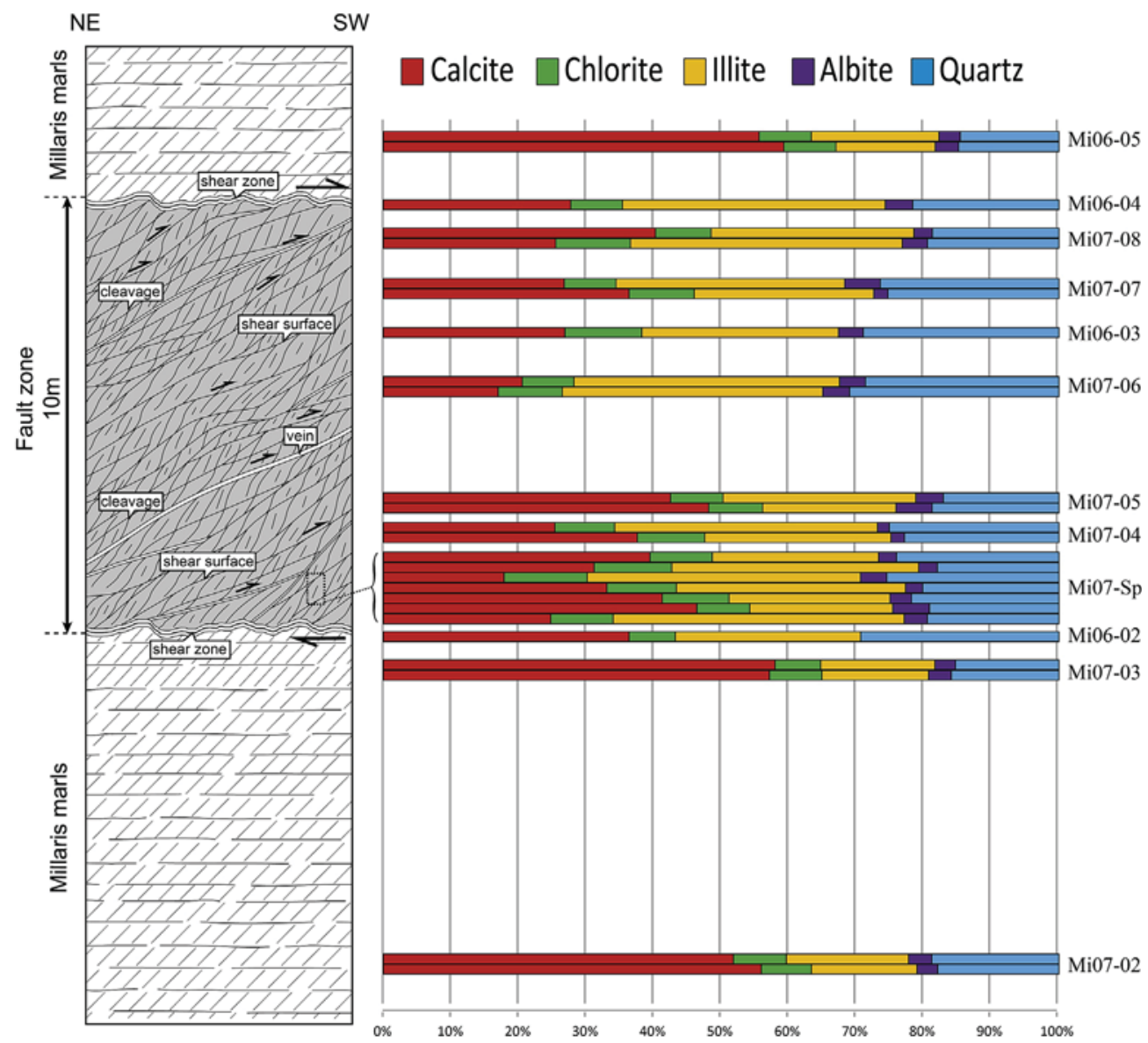

Figure 9. Proportions of minerals given by Rietveld refinement from XRD bulk powered rocks analyses. Results are in weight percent and located in the structural diagram. Eight samples have duplicates: a second powder made on another area of the collected block. Both powders were analysed separately, which allows us to estimate centimetre-scale heterogeneity. Mi07-Sp sub-samples were collected next to each other to estimate decimetre-scale heterogeneity.

to determine the mineral proportions. The results of Rietveld analysis were confirmed by normative mineralogy calculations combining XRF bulk chemical data with mineral microprobe analyses. We observed the same mineralogical assemblage: calcite, quartz, illite, chlorite and albite in various proportions between fault zone and host marl samples.
We used the isocon method based on the Gresens equation to characterise mass transfers, assuming that the initial state before fault deformation was close to the host marls present in the hanging wall and footwall.

The mass balance calculation, combined with the observation of the deformation structures of the fault zone, suggest that

Table 5

Mineral formulas used for modal distribution (A) and proportions in weight percentages obtained by this calculation (B).

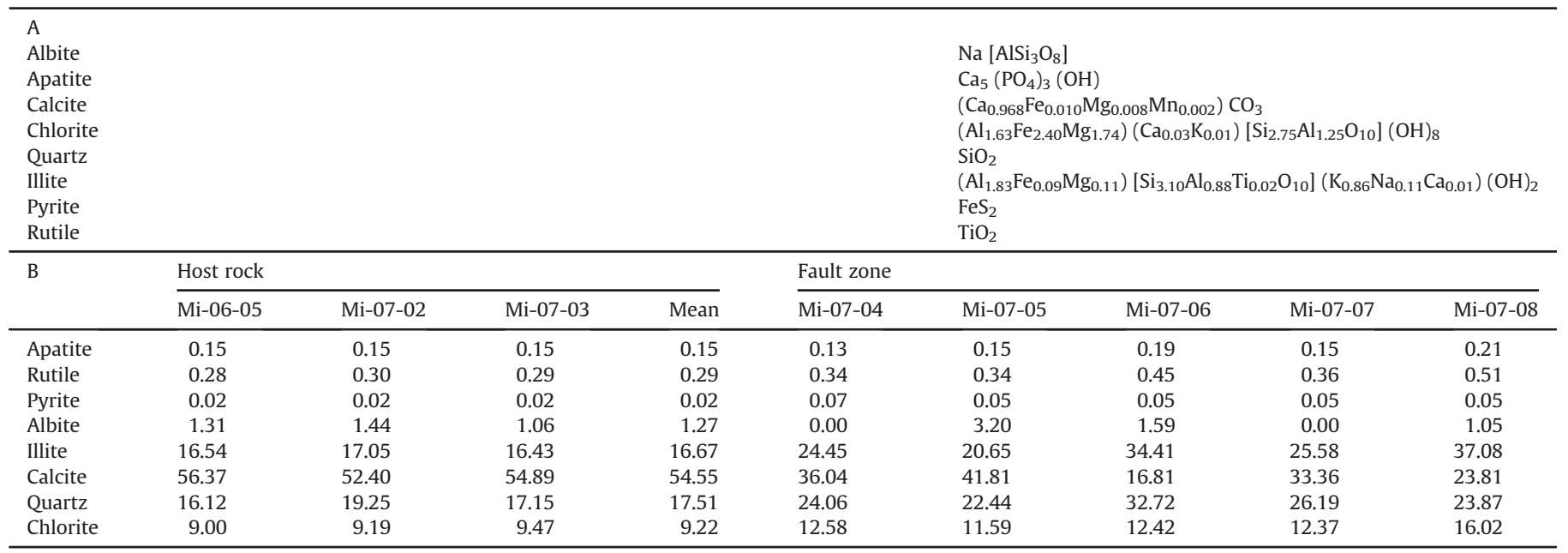




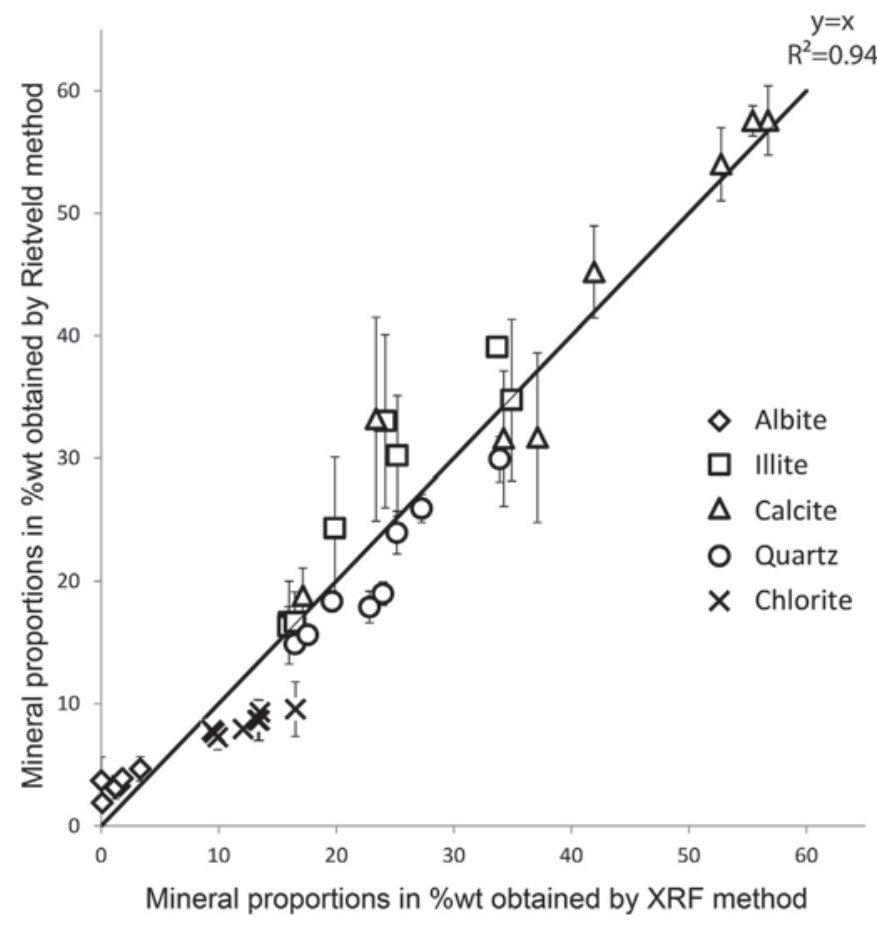

Figure 10. Correlation of mineral proportions in weight percentage given by Rietveld refinement and chemical (XRF) analyses. The chemical approximation is related to the accuracy of the XRF measurements, i.e. $0.1 \%$. In contrast, the error range of the Rietveld refinement is higher. It corresponds to the value of the standard deviation given by the Topas software that is multiplied by the GOF (goodness of fit) refinement value. The black line equation is $y=x$.

deformation induced a large volume loss by dissolution of micritic calcite. Calcite re-precipitated in veins. At the exception of calcium and dissolved $\mathrm{CO}_{2}$, other elements were immobile during deformation in the fault zone. At the fault zone scale, we can suggest that

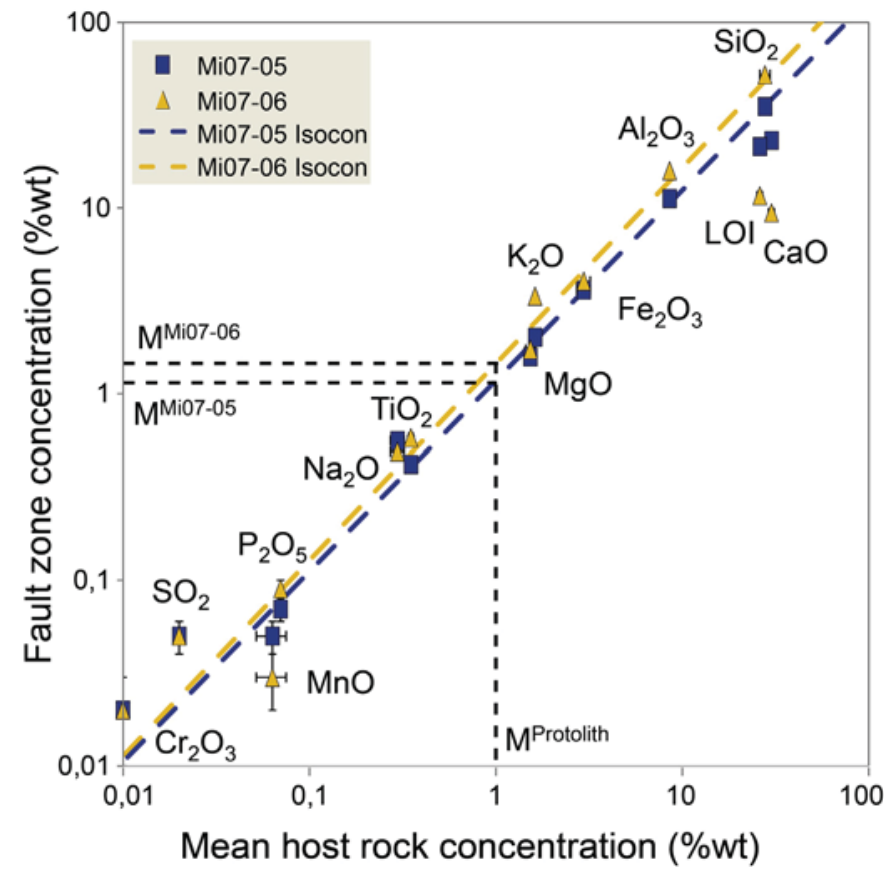

Figure 11. Isocon Grant (1986) representation for mass balance calculation. Samples Mi07-05 and Mi07-06 are considered as the less and the most deformed fault zone samples, respectively. The Isocon lines were drawn considering aluminium as immobile. LOI (loss on ignition): volatiles.

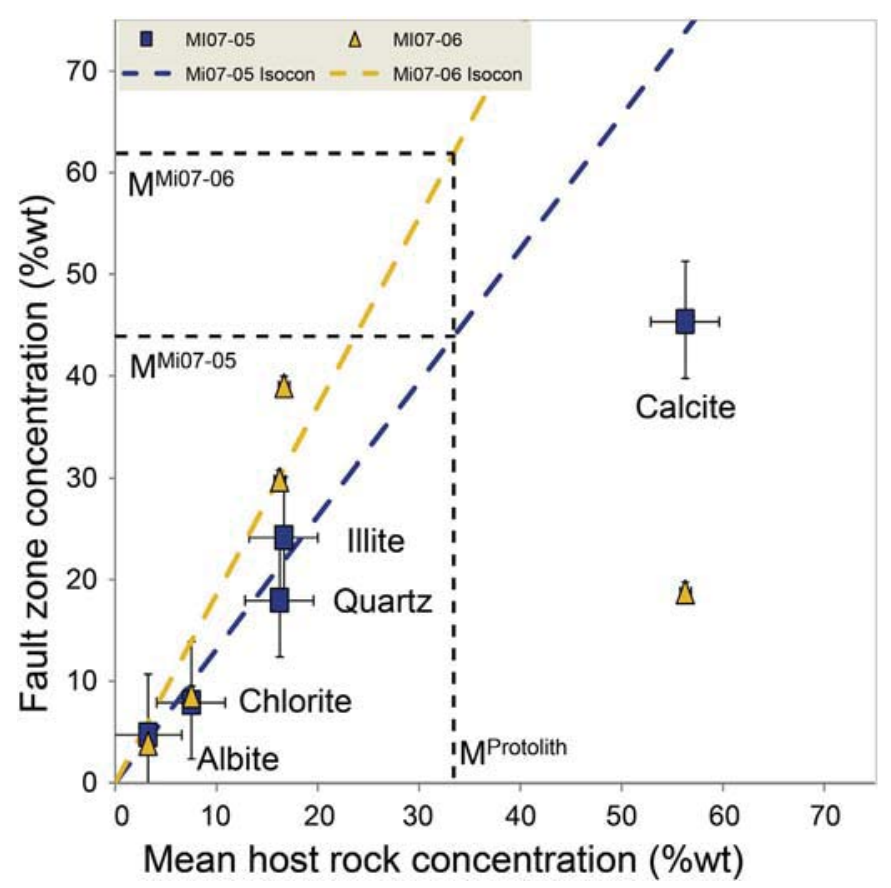

Figure 12. Isocon Grant (1986) representation from Rietveld analyses for mass balance calculation. The Isocon lines come from chemical data in Figure 11. As in Figure 11, samples Mi07-05 and Mi07-06 are considered as the less and the most deformed fault zone samples, respectively. For these two samples, two different powders from the same block were analysed and only the average of the two analyses is figured. It allows estimating the heterogeneity within the same rock sample, at the centimetre scale. The analytical error (Rietveld standard deviation * GOF) was also included in the error margins. For the host rock, an average was calculated from the three samples used (six powders analysed) as an error bar including analytical error on Rietveld refinement. Thus, for each point in this figure, the error bar is the heterogeneity of each sample added to the analytical error, hence to a maximum dispersion.

the deformation occurred in a closed chemical system; i.e. the loss of calcite in the fault zone matrix could have been compensated by the formation of calcite veins which is compatible with the isotopic data from Lacroix et al. (2012).

The deformation inside the fault zone induced calcite dissolution but also dissolution and recrystallisation of phyllosilicates. Newly-formed chlorites are richer in iron than in host rock, and $2 \mathrm{M}_{1}$ illites polytype recrystallisation are characteristic of low grade metamorphism conditions. The passive increase of phyllosilicates concentration in the fault rock matrix, as well as the recrystallisation of synkinematic clay minerals facilitated the weakening of the fault.

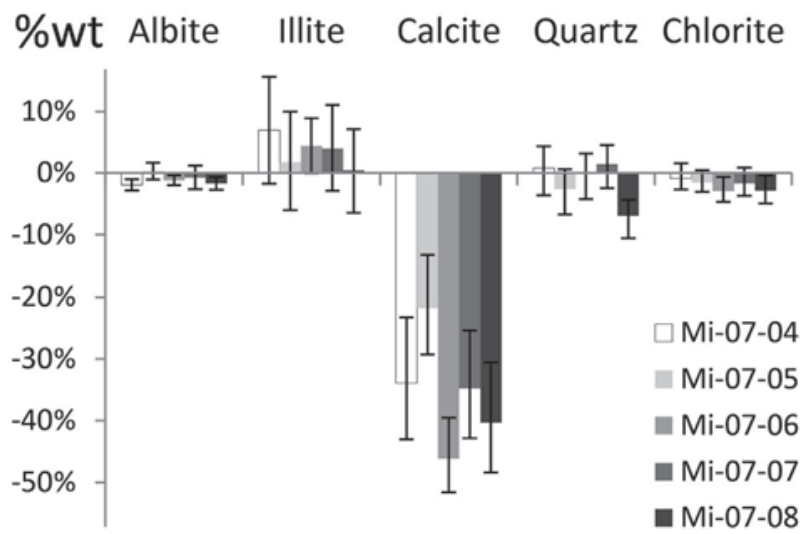

Figure 13. Mineral mass balance variations in weight percentages between host rock and fault zone samples calculated from Gresens' equation (1967). 

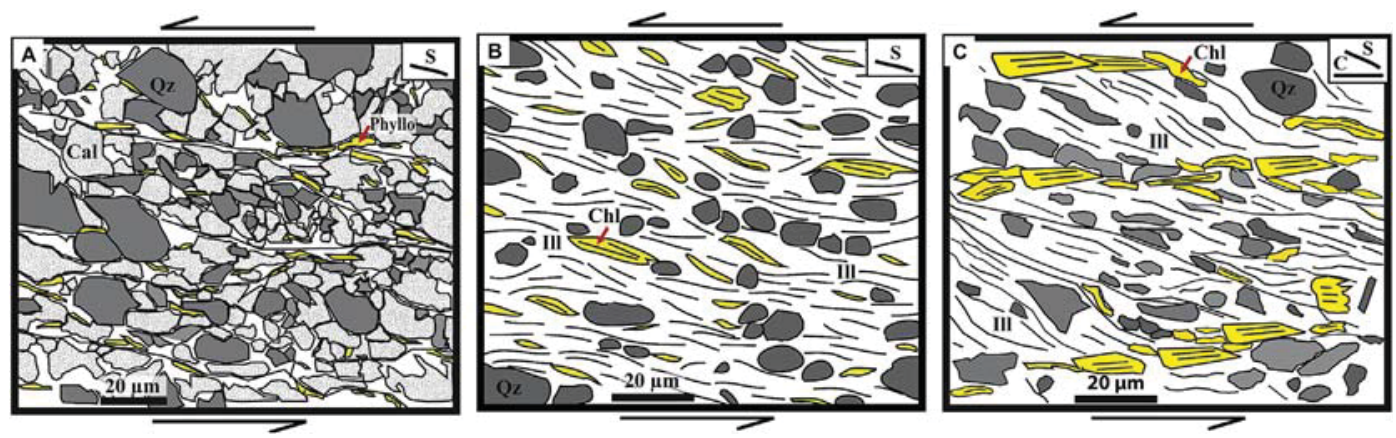

Figure 14. Sketch of deformation from host rock to intensively deformed fault zone. (A) Slightly deformed marls (similar to the present host rock). (B) Intermediate stage of deformation. (C) Final stage of deformation. During deformation, transfer mechanisms occur: calcite is dissolved and phyllosilicates as illite and chlorite are reoriented and recrystallised to form veins. This evolution is associated with the progressive development of microstructures with S-C fabric, with S: cleavage surfaces and C: shear surfaces. Key: Cal: calcite; Chl: chlorite; Ill: illite; Phyllo: phyllosilicate; Qz: quartz.

\section{Acknowledgements}

We address our thanks to Virginie Moutarlier, engineer in Femto laboratory of Besançon (France), for her help on the X-ray diffractometer and Rietveld refinement. This work was partly supported by the French RENATECH network. We extend our gratitude to $\mathrm{Mr}$ Dubacq and $\mathrm{Mr}$ Haines for the quality of the review and their precious advices.

\section{References}

Andrieux, P., Petit, S., 2010. Hydrothermal synthesis of dioctahedral smectites: the $\mathrm{Al}-\mathrm{Fe}^{3+}$ chemical series: part I: influence of experimental conditions. Appl. Clay Sci. 48, 5-17.

Baumgartner, L.P., Olsen, S.N., 1995. A least-squares approach to mass transport calculations using the isocon method. Econ. Geol. 90, 1261-1270.

Behnsen, J., Faulkner, D.R., 2012. The effect of mineralogy and effective normal stress on frictional strength of sheet silicates. J. Struct. Geol. 42, 49-61.

Boles, J.R., Eichhubl, P., Garven, G., Chen, J., 2004. Evolution of a hydrocarbon migration pathway along basin-bounding faults: evidence from fault cement. AAPG Bull. 88, 947-970.

Brindley, G.W., Brown, G., 1980. Crystal Structures of Clay Minerals and Their X-ray Identification. Mineralogical Society, p. 526.

Buatier, M.D., Lacroix, B., Labaume, P., Moutarlier, V., Charpentier, D., Sizun, J.P. Travé, A., 2012. Microtextural investigation (SEM and TEM study) of phyllosilicates in a major thrust fault zone (Monte Perdido, southern Pyrenees): impact on fault reactivation. Swiss J. Geosci. 105, 313-324.

Byerlee, J., 1978. Friction of rocks. Pure Appl. Geophys. PAGEOPH 116, 615-626.

Carpenter, B.M., Marone, C., Saffer, D.M., 2011. Weakness of the San Andreas Fault revealed by samples from the active fault zone. Nat. Geosci. 4, 251-254.

Cavailhes, T., Sizun, J.P., Labaume, P., Chauvet, A., Buatier, M., Soliva, R., Mezri, L., Charpentier, D., Leclère, H., Travé, A., Gout, C., 2013. Influence of fault rock foliation on fault zone permeability: the case of deeply buried arkosic sandstones (Grès d'Annot, southeastern France). AAPG Bull. 97, 1521-1543.

Charpentier, D., Buatier, M.D., Jacquot, E., Gaudin, A., Wheat, C.G., 2011. Conditions and mechanism for the formation of iron-rich Montmorillonite in deep sea sediments (Costa Rica margin): coupling high resolution mineralogical characterization and geochemical modeling. Geochim. Cosmochim. Acta 75, 13971410.

Cheary, R.W., Coelho, A., 1992. A fundamental parameters approach to X-ray lineprofile fitting. J. Appl. Crystallogr. 25, 109-121.

De Caritat, P., Hutcheon, I., Walshe, J., 1993. Chlorite geothermometry - a review. Clay Clay Miner. 41, 219-239.

Demény, A. Sharp, Z.D., Pfeifer, H.-R., 1997. Mg-metasomatism and formation conditions of Mg-chlorite-muscovite-quartz phyllites (leucophyllites) of the Eastern Alps (W. Hungary) and their relations to Alpine white schists. Contrib. Mineral. Petrol. 128, 247-260.

Dickin, A.P., 1988. Evidence for limited REE leaching from the Roffna Gneiss, Switzerland - a discussion of the paper by Vocke et al. (1987) (CMP95: 145154). Contrib. Mineral. Petrol. 99, 273-275.

Dideriksen, K., Christiansen, B.C., Baker, J.A., Frandsen, C., Balic-Zunic, T., Tullborg, E., Mørup, S., Stipp, S.L.S., 2007. Fe-oxide fracture fillings as a palæo-redox indicator: structure, crystal form and Fe isotope composition. Chem. Geol. 244, 330-343.

Faulkner, D.R., Rutter, E.H., 1998. The gas permeability of clay-bearing fault gouge at $20^{\circ} \mathrm{C}$. In: Geological Society, London, Special Publications 147, pp. 147-156.
Grant, J.A., 1986. The isocon diagram; a simple solution to Gresens' equation for metasomatic alteration. Econ. Geol. 81, 1976-1982.

Grant, J.A., 2005. Isocon analysis: a brief review of the method and applications. Phys. Chem. Earth A/B/C 30, 997-1004.

Gratier, J.-P., Thouvenot, F., Jenatton, L., Tourette, A., Doan, M.-L., Renard, F., 2013. Geological control of the partitioning between seismic and aseismic sliding behaviours in active faults: evidence from the Western Alps, France. Tectonophysics 600, 226-242.

Gresens, R.L., 1967. Composition-volume relationships of metasomatism. Chem. Geol. 2, 47-65.

Haines, S.H., van der Pluijm, B.A., 2012. Patterns of mineral transformations in clay gouge, with examples from low-angle normal fault rocks in the western USA J. Struct. Geol. 43, 2-32.

Hellmann, R., Daval, D., Tisserand, D., 2010. The dependence of albite feldspar dissolution kinetics on fluid saturation state at acid and basic pH: progress towards a universal relation. C.R. Geosci. 342, 676-684.

Hill, R.J., Howard, C.J., 1987. Quantitative phase analysis from neutron powder diffraction data using the Rietveld method. J. Appl. Crystallogr. 20, 467-474.

Hippertt, J.F., 1998. Breakdown of feldspar, volume gain and lateral mass transfer during mylonitization of granitoid in a low metamorphic grade shear zone. J. Struct. Geol. 20, 175-193.

Huang, W.L., 1992. Illitic-clay formation during experimental diagenesis of arkoses. In: SEPM Special Publication 47, pp. 50-63.

Huang, W.L., Bishop, A.M., Brown, R.W., 1986. The effect of fluid/rock ratio on feldspar dissolution and illite formation under reservoir conditions. Clay Miner. 21, 585-601.

Hunziker, J.C., Frey, M., Clauer, N., Dallmeyer, R.D., Friedrichsen, H., Flehmig, W. Hochstrasser, K., Roggwiler, P., Schwander, H., 1986. The evolution of illite to muscovite: mineralogical and isotopic data from the Glarus Alps, Switzerland. Contrib. Mineral. Petrol. 92, 157-180.

Labaume, P. Séguret, M., Seyve, C., 1985. Evolution of a turbiditic foreland basin and analogy with an accretionary prism: example of the Eocene South-Pyrenean Basin. Tectonics 4, 661.

Lacroix, B., 2011. Interaction fluide-roche et comportement des phyllosilicates à basses températures en contexte sédiementaire - exemple du prisme orogénique sud-pyrénéen (Thèse de doctorat). Université de Franche-Comté.

Lacroix, B., Buatier, M., Labaume, P., Travé, A., Dubois, M., Charpentier, D. Ventalon, S., Convert-Gaubier, D., 2011. Microtectonic and geochemical characterization of thrusting in a foreland basin: example of the South-Pyrenean orogenic wedge (Spain). J. Struct. Geol. 33, 1359-1377.

Lacroix, B., Charpentier, D., Buatier, M., Vennemann, T., Labaume, P., Adatte, T. Travé, A., Dubois, M., 2012. Formation of chlorite during thrust fault reactivation. Record of fluid origin and P-T conditions in the Monte Perdido thrust fault (southern Pyrenees). Contrib. Mineral. Petrol. 163, 1083-1102.

Lacroix, B., Leclère, H., Buatier, M., Fabbri, O., 2013. Weakening processes in thrust faults: insights from the Monte Perdido thrust fault (southern Pyrenees, Spain). Geofluids 13, 56-65.

Leclère, H., Buatier, M., Charpentier, D., Sizun, J.-P., Labaume, P., Cavailhes, T., 2012. Formation of phyllosilicates in a fault zone affecting deeply buried arkosic sandstones: their influence on petrophysic properties (Annot sandstones, French external Alps). Swiss J. Geosci. 105, 299-312.

Liang, J.-J., Hawthorne, F.C., 1994. Characterization of fine-grained mixtures of rockforming minerals by Rietveld structure refinement; olivine + pyroxene. Can. Mineral. 32, 541-552.

Lonka, H., Schulmann, K., Venera, Z., 1998. Ductile deformation of tonalite in the Suomusjärvi shear zone, south-western Finland. J. Struct. Geol. 20, 783-798.

Maxwell, D.T., Hower, J., 1967. High-grade diagenesis and low-grade metamorphism of illite in the Precambrian Belt Series. Am. Mineral. 52, 843-857.

McCaig, A.-M., Tritlla, J., Banks, D.-A., 2000. Fluid mixing and recycling during Pyrenean thrusting: evidence from fluid inclusion halogen ratios. Geochim. Cosmochim. Acta 64, 3395-3412. 
Merlet, C., Bodinier, J.-L., 1990. Electron microprobe determination of minor and trace transition elements in silicate minerals: a method and its application to mineral zoning in the peridotite nodule PHN 1611. Chem. Geol. 83, 5569.

Monicard, R., 1975. Cours de production: Caractérisation des roches réservoirs, analyse de carottes. In: Editions Technip (Ed.). Institut Français du Pétrole Publication, Paris, France, p. 203.

Moore, D.M., Reynolds, R.C., 1997. X-ray Diffraction and the Identification and Analysis of Clay Minerals. Oxford University Press, New York, p. 322.

Muñoz, J.A., 1992. Evolution of a continental collision belt: ECORS-Pyrenees crustal balanced cross-section. In: McClay, K.R. (Ed.), Thrust Tectonics. Springer Netherlands, Dordrecht, pp. 235-246.

Mutti, E., Séguret, M., Sgavetti, M., 1988. Sedimentation and deformation in the Tertiary sequences of the southern Pyrenees. In: AAPG Mediterranean Basins Conference, Field Trip 7, p. 153.

Numelin, T., Marone, C., Kirby, E., 2007. Frictional properties of natural fault gouge from a low-angle normal fault, Panamint Valley, California. Tectonics 26, TC2004.

O'Hara, K., 1988. Fluid flow and volume loss during mylonitization: an origin for phyllonite in an overthrust setting, North Carolina U.S.A. Tectonophysics 156, 21-36.

Oliva-Urcia, B., Larrasoaña, J.C., Pueyo, E.L., Gil, A., Mata, P., Parés, J.M., Schleicher, A.M., Pueyo, O., 2009. Disentangling magnetic subfabrics and their link to deformation processes in cleaved sedimentary rocks from the Internal Sierras (west central Pyrenees, Spain). J. Struct. Geol. 31, 163-176.

Post, J.E., Bish, D.L., 1989. Rietveld refinement of crystal structures using powder Xray diffraction data. Rev. Mineral. Geochem. 20, 277-308.

Potdevin, J.L., Marquer, D., 1987. Méthode de quantification des transferts de matière par les fluides dans les roches métamorphiques déformées. Geodin. Acta 1, 193-206.

Rahl, J.M., Haines, S.H., van der Pluijm, B.A., 2011. Links between orogenic wedge deformation and erosional exhumation: evidence from illite age analysis of fault rock and detrital thermochronology of syn-tectonic conglomerates in the Spanish Pyrenees. Earth Planet. Sci. Lett. 307, 180-190.

Raynaud, S., Carrio-Schaffhauser, E., 1992. Rock matrix structures in a zone influenced by a stylolite. J. Struct. Geol. 14, 973-980.

Renard, F., Ortoleva, P., Gratier, J.P., 1997. Pressure solution in sandstones: influence of clays and dependence on temperature and stress. Tectonophysics 280, 257266.

Rietveld, H.M., 1969. A profile refinement method for nuclear and magnetic structures. J. Appl. Crystallogr. 2, 65-71.
Rosen, O.M., Abbyasov, A.A., Tipper, J.C., 2004. MINLITH - an experience-based algorithm, for estimating, the likely mineralogical compositions of sedimentary rocks from bulk chemical analyses. Comput. Geosci. 30, 647-661.

Roure, F., Choukroune, P., Berastegui, X., Munoz, J.A., Villien, A., Matheron, P., Bareyt, M., Seguret, M., Camara, P., Deramond, J., 1989. Ecors deep seismic data and balanced cross sections: geometric constraints on the evolution of the Pyrenees. Tectonics 8, 41-50.

Séguret, M., 1972. Etude tectonique des nappes et series decollees de la partie centrale du versant sud des Pyrenees: caractere synsedimentaire, rôle de la compression et de la gravite. ISSN: 0992-4191. Publications de l'Université des sciences et techniques du Languedoc. Série Géologie structurale. Laboratoire de géologie structurale-USTL, Montpellier, France.

Selverstone, J., Morteani, G., Staude, J.-M., 1991. Fluid channelling during ductile shearing: transformation of granodiorite into aluminous schist in the Tauern Window, Eastern Alps. J. Metamorph. Geol. 9, 419-431.

Steyrer, H.P., Sturm, R., 2002. Stability of zircon in a low-grade ultramylonite and its utility for chemical mass balancing: the shear zone at Miéville, Switzerland. Chem. Geol. 187, 1-19.

Tabelin, C.B., Igarashi, T., Tamoto, S., Takahashi, R., 2012. The roles of pyrite and calcite in the mobilization of arsenic and lead from hydrothermally altered rocks excavated in Hokkaido, Japan. J. Geochem. Explor. 119, 17-31.

Taylor, J.C., Hinczak, I., 2003. Rietveld Made Easy: [A Practical Guide to the Understanding of the Method and Successful Phase Quantifications]. Sietronics Pty Ltd, Canberra, Australia, p. 201.

Teixell, A., 1996. The Anso transect of the southern Pyrenees: basement and cover thrust geometries. J. Geol. Soc. 153, 301-310.

Teixell, A., 1998. Crustal structure and orogenic material budget in the west central Pyrenees. Tectonics 17, 395-406.

Teixell, A., 2000. Geotectónica de los Pirineos. Investig. Cienc. 288, 54-65.

Toby, B.H., 2006. R factors in Rietveld analysis: how good is good enough? Powder Diffr. 21, 67-70.

Turner, C.E., Fishman, N.S., 1991. Jurassic Lake T‘oo'dichi': a large alkaline, saline lake, Morrison Formation, eastern Colorado Plateau. Geol. Soc. Am. Bull. 103, 538-558.

Yoder, H.S., Eugster, H.P., 1955. Synthetic and natural muscovites. Geochim. Cosmochim. Acta 8, 225-280.

Young, R.A., 1993. The Rietveld Method, first ed. Oxford University Press, USA.

Zane, A., Sassi, R., Guidotti, C.V., 1998. New data on metamorphic chlorite as a petrogenetic indicator mineral, with special regard to greenschist-facies rocks. Can. Mineral. 36, 713-726.

Zinszner, B., Pellerin, F.M., 2007. A Geoscientist's Guide to Petrophysics. Editions Technip, Paris, p. 450. 